\title{
$8 \quad$ Visual Art and Historical Representation in Ancient Greece and China
}

\author{
JEREMY TANNER
}

Comparisons between Greek and Chinese history writing have a long genealogy. Their visual counterparts do not, although they include canonical works of early Greek and Chinese art, from the Tyrannicides of early fifthcentury Athens (Figure 8.1) to the Wu Liang Shrine in Han China (Figure 8.2). Drawing on recent approaches to 'regimes of historicity', this chapter explores how the past is brought into play and 'set on stage' in the present in the visual art of ancient Greece and China. ${ }^{1}$ It focuses on the social agents who put history on stage, the institutional contexts of presentations of the past and their consumption, the distinctive cultural and material strategies that inform such stagings, and the capacity of such representations of the past to shape the larger social worlds within which they circulate. Taking a long-term perspective, I argue that, notwithstanding differences in scale, social structure and political organisation between late Bronze Age Chinese states and their archaic Greek counterparts, there are significant parallels in the ways visual art was used to materialise the past in the present. By means of 'ancestralising strategies' elite kin groups sought privileged positions within weakly integrated states, using visual (and textual) media to link themselves to heroic and even divine forebears whose charisma they appropriated. Exploring the development of visual depictions of history in early imperial China and classical Athens, I analyse the role played by an increasingly differentiated state in creating pictures of historical events as a new medium of collective memory. The use and character of such depictions were shaped by the differing balance of power amongst key constituencies controlling the cultural apparatus of the state and the broader public sphere: the imperial bureaucracy and the shi (literati) in China, the dèmos and the political elite, the orators and generals, of classical Athens.

\section{Staging History through Visual Art}

Significant differences between Greek and Chinese history writing have been explained in terms of the specific literary models which informed

${ }^{1}$ Hartog 2000, 2003; Detienne 2007: 53. 


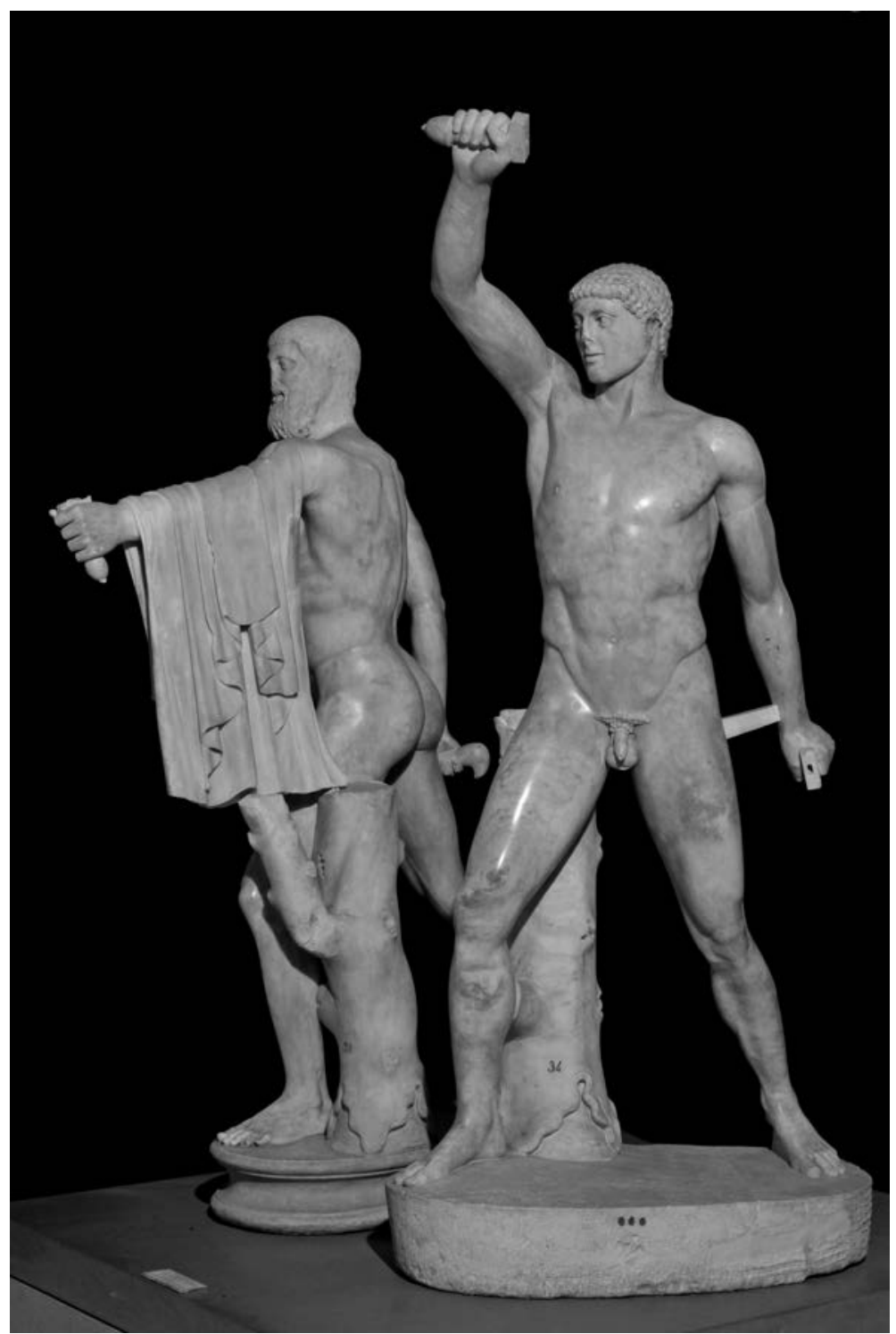

Figure 8.1 Tyrannicides: Harmodius and Aristogeiton. Roman marble copy of bronze statues by Kritios and Nesiotes, 476 BCE.

their beginnings and cut across the broadly parallel development of selfconscious historical awareness in the two traditions. Herodotus' account of the Persian Wars and Thucydides' history of the Peloponnesian War are characterised by their focus on war, a unified structure and continuous narrative, all features attributed to the model of epic poetry. Sima Qian's 


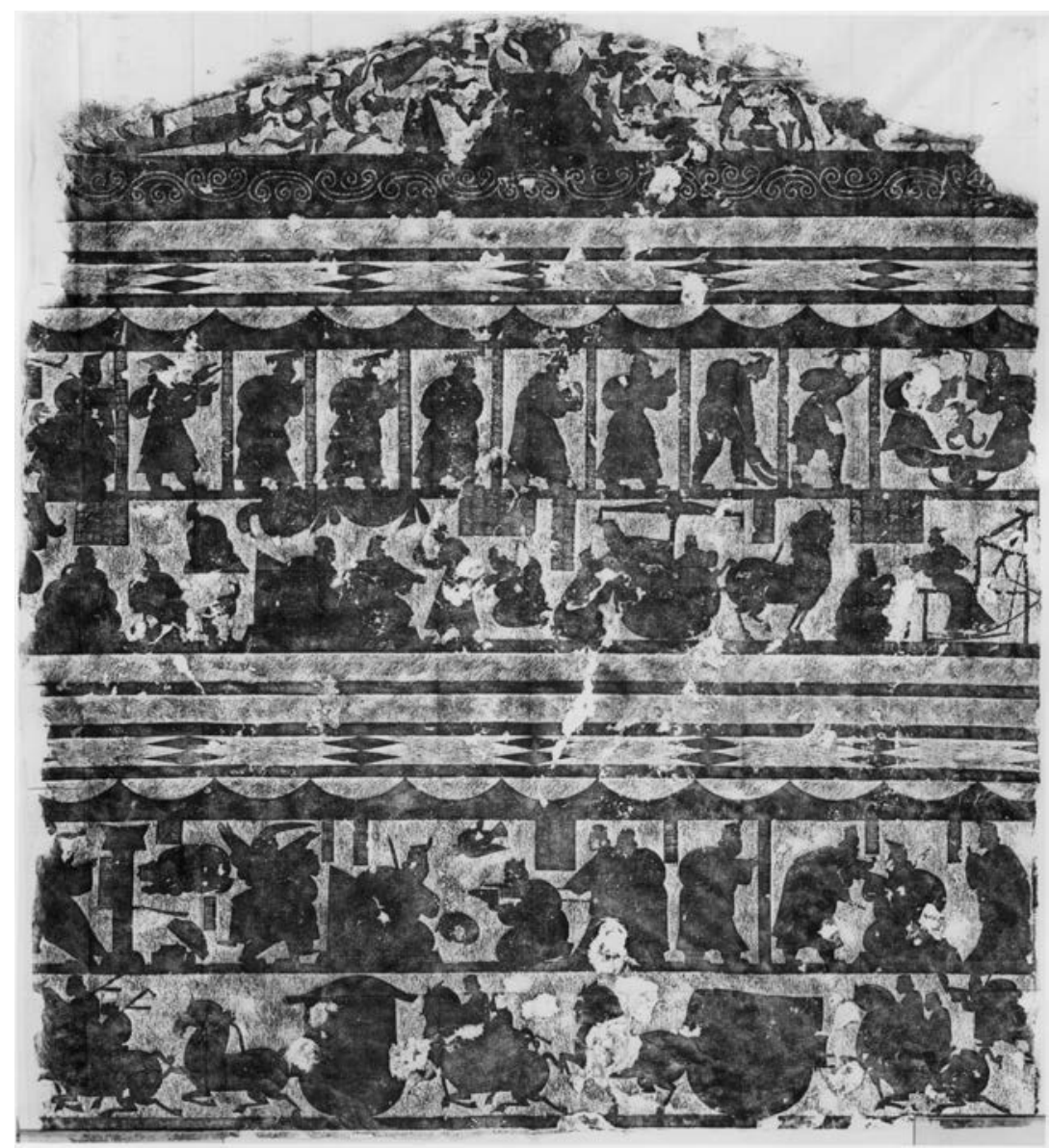

Figure 8.2 Wu Liang Shrine, West Wall. Second century CE. Rubbing after the original stone engravings.

Records (Shiji), by contrast, is divided into sections which correspond to categories of social hierarchy: the annals of the ruling dynasty, histories of the noble houses, and collections of biographies of famous men of lower social status, paralleling early Chinese lyric, in particular the Classic of Poetry, an anthology of poems concerning the lives of ordinary people (Book 1), the noble houses (Books 2-3), and the state rites of the ruling dynasty (Book 4). This background is held to inform the affective orientation of history writers to their past: the broadly objective, radically secular and scientific history of Thucydides is contrasted with the 'participationist' orientation of Sima Qian's history, where both author and reader are empathetically involved with the events narrated, in the context of a 
broader vision of man's place within the patterns of a dynamically transforming cosmos. ${ }^{2}$

Art historians' accounts of the picturing of history in early Greece and China apparently confirm this impression of distinctive cultural mentalities fully articulated in historical texts and reflected in the corresponding visual art. Wu Hung has demonstrated how the Wu Liang Shrine is organised in terms of the same social and cultural categories as the Shiji, ${ }^{3}$ even appropriating captions for the pictures from the Shiji. ${ }^{4}$ Hölscher has drawn similar parallels between history writing and history painting in classical Greece: both manifested processes of cultural secularisation and the establishment of critical reflective distance from the horizons of archaic thought, elements of the transformation from a life lived in tradition to one lived in history. ${ }^{5}$

Approaching pictorial representations of history in terms of their parallels with textual counterparts, however, naturalises the category of 'history' in ways increasingly seen as problematic. Modern disciplinary concepts of 'history', formulated in the nineteenth century, cannot be straightforwardly applied to the investigations of Herodotus' historia ('inquiry'), or to the activities of Sima Qian in compiling his 'records'. ${ }^{6}$ The category of 'history painting' is not an ancient one in either Greece or China, but the formulation of the Renaissance art theorist Alberti, describing narrative representations in general, and later codified as a category of Academic painting theory.? Recent work has relativised the modern disciplinary concept of history, seeing it as merely one orientation to the past amongst others. ${ }^{8}$ Whilst some kind of orientation towards the past is an anthropological universal, the character of such orientations is diverse in terms of the material modes and cultural forms in which the past can be accessed, encoded, and represented in relation to contemporary events and social purposes. ${ }^{9}$ Different 'memory strategies' realised through different media may vary widely in the ways in which they transform experiences into accounts of the past which in turn can have variably binding effects on futures. ${ }^{10}$ The concept of 'memory strategies' implies agents who pursue those strategies, constructing representations of the past which are perspectival, shaped by 'an interest structure

\footnotetext{
2 Prusek 1970; Mutschler 1997; Shankman and Durrant 2000: 90-120. $\quad{ }^{3} \mathrm{Wu} 1989$.

${ }^{4}$ While the inscriptions are the most likely elements of the shrine to have been recarved in more recent times (Liu, Nylan and Barbieri-Low 2005), arguments that the shrines are eighteenthcentury forgeries are not persuasive. The closely related Songshan shrines, for example, come from a reliable archaeological context: Bai 2008; Akiro 2010.

${ }^{5}$ Hölscher 1973: 201-6; 1988: $115 .{ }^{6}$ Lloyd 2011; 2002: 2-12. ${ }^{7}$ Goldstein 1996: 40-1.

${ }^{8}$ Rusen 1996. ${ }^{9}$ Hirsch and Stewart 2005. ${ }^{10}$ Assmann 2011: 50-60.
} 
that is dependent on specific life situations' in the present. ${ }^{11}$ Within any society, a variety of competing historicities may be at play, linked to differing institutional contexts, to distinctive media and traditions of representation, and to specific social groups who are the bearers of such traditions.

Emphasis on comparative study of 'historicities' underlines the variety of representations of the past at play at any one time, rather than assuming a uniform Greek or Chinese 'historical consciousness'. It brackets the debate over whether the works of Herodotus and Sima Qian, or of the artists of the Stoa Poikile and the Wu Liang Shrine, are 'true history' or not. Instead, it sees the status of 'true history' as one of the stakes at play within cultures of historical representation themselves: different modes of historical representation are constituted through different kinds of performance, using 'framing devices' which make varying rhetorical claims about the truth value of the representations in question. ${ }^{12}$ Paradoxically, it is the attack on unreliable popular accounts of the past, in both textual and visual narratives, which allows us to recognise the existence in classical Greece and Han China of some concept of works of visual art as vehicles for history, not mere myth or fancy, bearing a family resemblance, if a rather distant one, to their more recent Western counterparts. The stories concerning the Tyrannicides, the founding fathers of Athenian democracy, as narrated in works like the famous statue group, are attacked by Thucydides for their largely fictional character, contrasting with the accuracy (akribeia) of his own history. ${ }^{13}$ Similarly, the Han essayist Wang Chong attacks paintings retailing popular accounts of $\mathrm{Wu} \mathrm{Zixu}$, 'seeming to be true, but in fact unreal': the surviving consciousness of this loyal minister of the fifth century, boiled alive in a cauldron and then dumped into a river, was manifested, it was held, by the stormy waves he stirred up on the river to revenge himself upon an ungrateful world. ${ }^{14}$

\section{Pre-History: Visual Art and Ancestral Memories in Archaic Greece and Late Bronze Age China}

Bronze Age China of the Western Zhou (1045-771 BCE) has been characterised as a 'delegatory kin-ordered settlement state': ${ }^{15}$ city-states were ruled by local dynasties whose position depended on their seniority within a hierarchy of patrilineal corporate groups, leading up to the Zhou king, the

11 Frisby 1992: 9. ${ }^{12}$ Alonso 1988: $35 . \quad{ }^{13}$ Thucydides 6.53-9.

${ }^{14}$ Lunheng 4.1, trans. Forke II, 247-51; Wang 1994. ${ }^{15}$ Li 2008: 23. 
head of the most senior lineage, from whom the authority of settlement lineages was in theory delegated, notwithstanding their considerable practical autonomy. ${ }^{16}$ The paramount prestige symbols of this political order were bronzes, used in the context of ancestral cults. The right and possibly the material to make such vessels were awarded to their owners by the Zhou king at court ceremonials, when members of the aristocracy were honoured for their services and appointed to, or confirmed in, titles and positions within the court hierarchy. ${ }^{17}$

The vessels, and their inscriptions, were major vehicles of historical memory. They recorded events of investiture which thereby entered the historical memory of lineages and could be reproduced in subsequent generations during ancestral sacrifices at lineage temples. They reached back in time, recording a history of merit (gong 功) and service to the Zhou state by ancestors of the honorand, as exemplified by an eleventh-century zun (Figure 8.3) recording the honouring of one He by Cheng Wang:

It was at the time when the king began the building of the Cheng Zhou, and offered a Fu sacrifice in the Hall of Heaven to [his father] Wu Wang. In the fourth month, on the day bing $x u$, the king was in the Jing Hall and exhorted me saying: 'In days past, your late ancestor Gong Shi was able to serve Wen Wang. Wen Wang accepted the great command, and Wu Wang carried out the conquest of the Great City of Shang, announcing it to Heaven with the words: "I must dwell in the center, and from there rule the people". Now take heed! You must cherish the memory of the services that Gong Shi rendered to Heaven. Sacrifice to him with reverence!' Our king has indeed a virtuous character, compliant with Heaven, an inspiring example to my own feebleness. When the king had concluded, I, He, was given thirty strings of cowries, which I have used to make this vessel for sacrifices to Gong Shi. This happened in the king's fifth year. ${ }^{18}$

The Shi Qiang Pan (Figure 8.4), a large water vessel, exemplifies the historical character of such bronzes. The elaborate inscription presents a eulogy of seven generations of Zhou kings, before celebrating the services to the Zhou of the ancestors and immediate ascendants of Scribe Qiang: he dedicates the vessel for use in the ancestral cult, hoping that the 'vibrant freshness, fortunate peace and blessed wealth' afforded by these satisfied ancestors will enable him to continue to 'be worthy to preserve his ruler' during the course of a 'prolonged life'. ${ }^{19}$ These inscribed histories are designed for their ritual context. Formulated for investiture ceremonies,

\footnotetext{
${ }^{16}$ Keightley 1990: 46-7; Falkenhausen 2005: 240; Li 2008. ${ }^{17}$ Bagley 1980a; Kern 2009: 163.

18 Bagley 1980a: 198, 203-4.

19 Bagley 1980a: 198; Shaughnessy 1991: 1-4, 183-92; 1999: 242-4.
} 


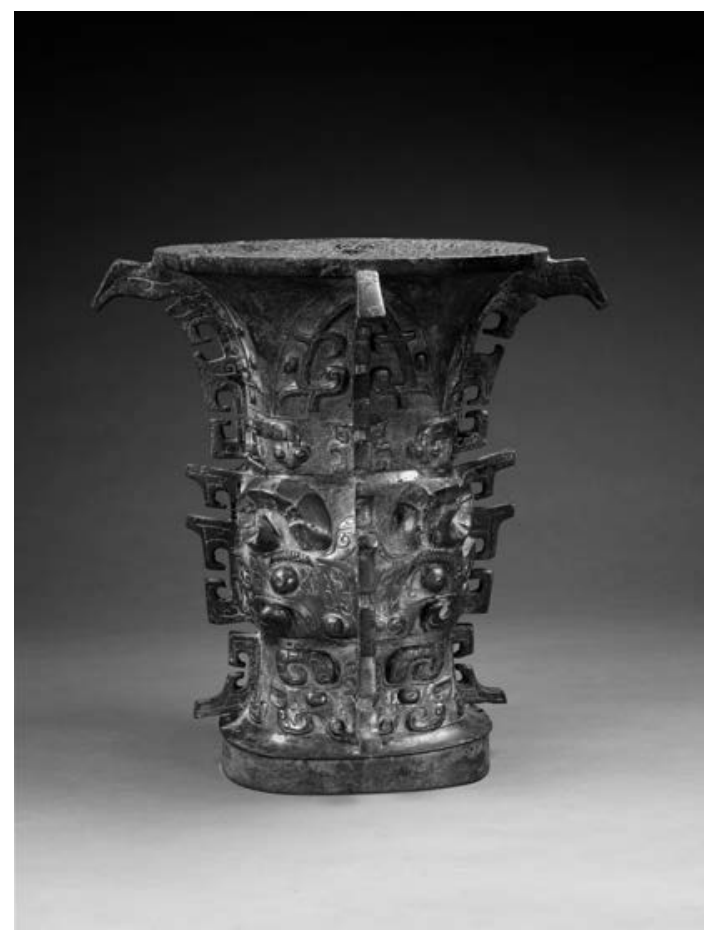

Figure 8.3(a) He zun, eleventh century BCE.

and intended to procure the satisfaction and support of ancestors, they present the achievements of both the Zhou and lineage ancestors in a favourable light. The Shi Qiang Pan celebrates King Zhao's subjugation of the Chu and the Jing in the south, but fails to mention that both the king and his army were annihilated during the campaign. ${ }^{20}$ The ancestral lines recorded on bronzes could be manipulated, and even partially invented, to include an ancestor among the founders of the Zhou royal house, and to realise an ideal coordination with the Zhou royal succession, thus demonstrating generations of loyalty on the part of the lineage to the Zhou, ${ }^{21}$ ancestralising practices with close parallels among the aristocracies of archaic Greece.

Bronzes' efficacy as media for historical memory depended on their role in sacrifices made to ancestors in lineage temples. Accumulating over time, vessel collections materially embodied lineage history. The distinction of that history could be seen at a glance: the Shi Qiang Pan is one vessel from a hoard of 103 bronzes, 74 of them marked with the same clan name, and

${ }^{20}$ Kern 2009: 152-3. $\quad{ }^{21}$ Falkenhausen 2005: 248-9, 267-75. 


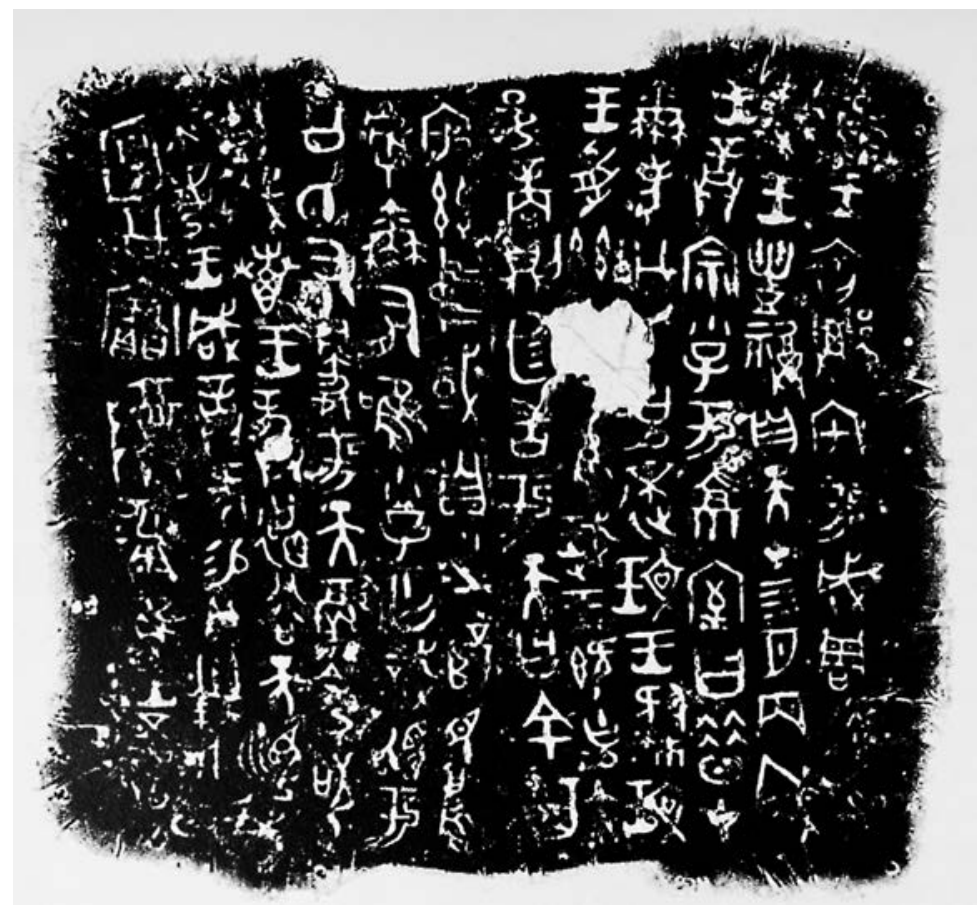

Figure 8.3(b) Rubbing of the inscription from the interior of the He zun.

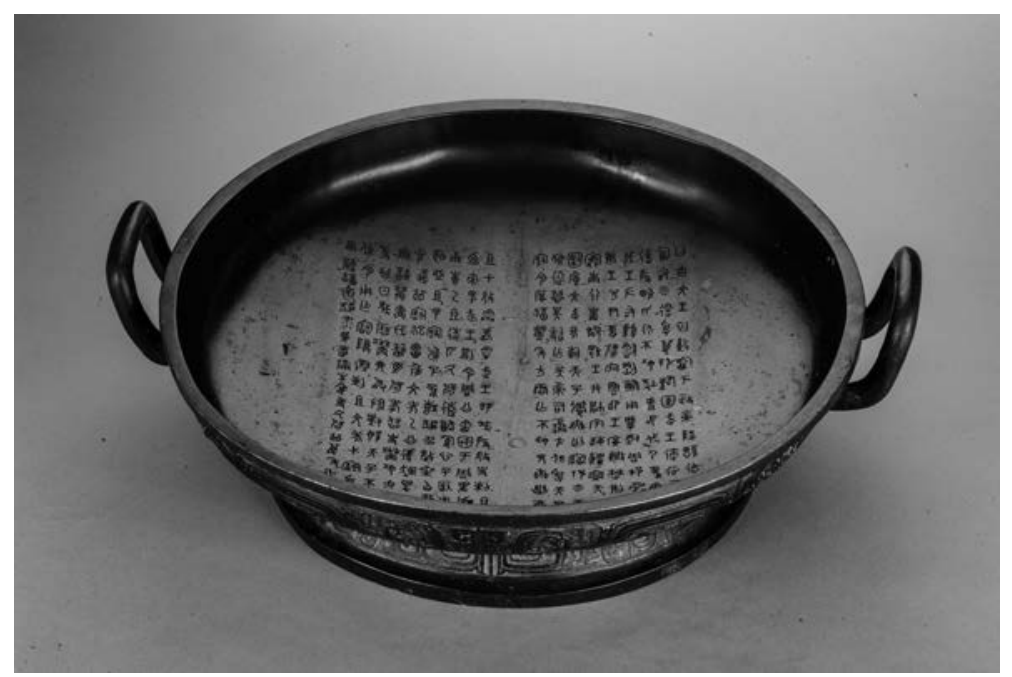

Figure 8.4 Shi Qiang bronze pan vessel, tenth century BCE. Zhuangbai, Fufeng, Shaanxi Province. 
spanning the entire history of the Western Zhou. ${ }^{22}$ Within such massive assemblages, the design of bronzes as sets facilitated the identification of vessels associated with specific ancestors, and hence the appropriate performance of sacrifices. ${ }^{23}$ The ritual actions involved in the performance of ancestral sacrifice were mediated by the material affordances of the bronzes - shape, weight and design encoding appropriate bodily movements. ${ }^{24}$ Ritual performance permitted the spirits of the ancestors to mingle with those of the living: life-giving sacrifice flowed in one direction, ancestral blessings returned. ${ }^{25}$ Read aloud, or simply viewed, the primary recipients of inscriptions, alongside the living lineage community, were the ancestors. The inscriptions are often placed in inaccessible recesses within vessels, or at the bottom of the interior (as on the He $z u n$ ), largely covered by food or drink offerings during the ceremonies. ${ }^{26}$ Bronzes, in this ritual context, were both index of and medium for the accumulation of de (德), the 'virtuous force' which sustained the life-forces and power of the lineage, ${ }^{27}$ guaranteeing history future through history past, joined in the historic present of commemorative ritual. Successfully performing the sacrifice, and hosting the banquet, the sacrificier demonstrated his piety, and transformed himself into an ideal successor to the ancestor commemorated, to be venerated himself for generations to come. ${ }^{28}$ This orientation to a historical future was marked in the conventional closing formula of ritual bronze inscriptions: 'may sons of sons, grandsons of grandsons forever treasure and use [this sacrificial vessel]'. ${ }^{29}$

In the Eastern Zhou, bronzes became increasingly popular, as cities and states repudiated Zhou hegemony and local rulers sought to institute their own local systems of lineage hierarchy and exchange of ritual bronzes as prestige goods. ${ }^{30}$ But they also lost some of their ritual character, as the 'old economy of gift exchange in ritually prescribed events' was displaced by the monetary economy and rationalising polities of the Warring States. ${ }^{31}$ Long inscriptions disappeared, replaced by embellishments such as inlays and engraved pictures, on smaller, lighter bronzes, luxury objects for personal use, eschewing the monumental character of traditional bronzes, whose scale and decoration were determined by their ritual function. ${ }^{32}$ By the Han, most bronze vessels were little more than 'cook pots and canisters'; ${ }^{33}$ other objects had become the focus of ritual investment.

\footnotetext{
22 Bagley 1980b: 241; Shaughnessy 1999: 236-47: collection from ancestral temple, buried during Quan Rong invasion.

${ }^{23}$ Rawson 1999: 113-19. $\quad{ }^{24}$ Rawson 1999: 117. $\quad{ }^{25}$ Kern 2009: $153 . \quad{ }^{26}$ Cook 2005: 11.

27 Cook 2005:14; Kern 2009: 151-2. $\quad{ }^{28}$ Kern 2009: 180-1. ${ }^{29}$ Kern 2009: 154.

${ }^{30}$ So 1980a. ${ }^{31}$ Cook 2005: 10. ${ }^{32}$ So 1980b: 308-9. ${ }^{33}$ Cook 2005: 9-10.
} 
The art and the societies of archaic Greece and late Bronze Age China might seem too dissimilar for fruitful comparison. Zhou China manifests continuities with the Shang, in terms of scale, social complexity and artistic technologies. Iron Age Greece develops from a drastically restricted base demographically, sociologically and artistically - following the collapse of the Bronze Age Mycenaean civilisation. ${ }^{34}$ There is no real parallel in the Greek case for the unilineal descent groups 'linked by kinship and bound by common property and religious cult' found in Zhou, and later, China: ${ }^{35}$ the civic community of the polis with its public assembly seems always to have transcended the family as the paramount social organisation, visible already as early as the Homeric poems. ${ }^{36}$ There are nevertheless significant parallels with the Chinese case in the ways works of art were used as anchors for historical memory in archaic Greece. As in China, ${ }^{37}$ gift giving and ritualised exchange inform memory practices which underwrite the authority of aristocratic elites. Although there is no cult of ancestors as such, or at least nothing of the formality, scale and sociological presence of ancestor worship in Zhou China, ancestralising strategies certainly informed the memory practices of elite families in archaic Greece.

In archaic Greece, the closest counterparts to Chinese bronzes as material anchors of historical memory, and as objects to be treasured (bao 璸), were agalmata, objects in which their owners might take delight (agallein). Whilst such objects have nothing material in common with Chinese ritual bronzes - and little material unity amongst themselves - they manifest a common logic in their operation as embodiments of value and objects of memory. Like ritual bronzes, they are acquired through forms of exchange that promote the personal merit of both giver and recipient, and which stand in strong contrast to commercial relationships. ${ }^{38}$ They are often made of some intrinsically valuable and enduring material, such that they can be transmitted down the generations, acquiring social value by virtue of their pedigree and the historical memories with which they are associated. Ritualised feasting amongst aristocratic guest friends offers one of the primary occasions for realising the historical memories embodied in such objects and for their exchange. ${ }^{39}$ Some objects are transmitted straightforwardly down a family line, embodying its history, and legitimating its authority, analogously to the bronzes of China: the sceptre of Agamemnon, for example, was made by the god Hephaistos, and given by Hermes to Zeus, the king of the gods, who presented it to Pelops, from

\footnotetext{
34 Osborne 1996: 18-50; Whitley 2001: 77-101. ${ }^{35}$ Zhou 2010: 12.

36 Osborne 1996: 147-60; Raaflaub 1997. ${ }^{37}$ Cook 2005: 10.

38 Gernet 1981; Csapo and Miller 1998: $99 . \quad{ }^{39}$ Grethlein 2008.
} 
whom it passed down the family line, Atreus, Thyestes and Agamemnon. ${ }^{40}$ Other objects accumulate pedigree by means of more entangled histories of transmission, like the boars-tusk helmet of Meriones: stolen from Amyntor, the grandfather of Odysseus, presented as a xenia gift to Amphidamas, and then Polos, inherited by his son Meriones, who in turn gives it to Odysseus, so the object returns to its family. ${ }^{41}$ Like Chinese bronzes, such agalmata are paramount prestige symbols, objects in which extraordinary, even divine, artistic and technical skill had been invested, which would preserve the memory of their former owners when used by their successors. ${ }^{42}$ Of course, there are differences in both the memory practices and the objects which mediate them: the exchanges in the Greek case are as likely to be lateral (between guest friends), as vertical (between generations of a family), and are not capped by any paramount ruler corresponding to the Zhou king. Further, the pattern of exchange and the typology of objects exchanged are less codified, less institutionally crystallised. But these differences represent variations in practices which have at least a family resemblance, variations which correspond to the limited development of state structures in the early Iron Age Greek world, and the smaller scale of social and political organisation, compared with Western Zhou China.

The concept of agalma, and ancestralising practices oriented to forebears as far back as the Bronze Age, remained important to the aristocratic elites of the Greek world throughout the archaic period, although the character of these practices changed over time in the context of ongoing struggles between elitist aristocrats, emulative of the hierarchical regimes of the Near East and Egypt, and other social groups favouring a more egalitarian civic culture. ${ }^{43}$ In the eighth century BCE, tomb cults were established in Mycenaean tholoi and rock-cut tombs in some regions of mainland Greece, notably Attica and Argos, as means to establish 'ancestral' land rights. ${ }^{44}$ Some, like the Menidhi tholos in Attica, become the focus in the seventh century of dedications of special categories of pottery (ritual vessels, decorated in an orientalising style), deposited in offering trenches distinct from the burials themselves, indicative of something other than simple grave goods. ${ }^{45}$

Without texts, we cannot be specific about the kinds of ancestral memory that such practices sustained, but sixth-century evidence permits sharper resolution. A new type of statue, the kouros (youth), based on

\footnotetext{
${ }^{40}$ Iliad 2.100-9. ${ }^{41}$ Iliad 10.261-90. ${ }^{42}$ Grethlein 2008: 37-40; Odyssey 15.54-5, 8.431-2.

43 Morris 2000. ${ }^{44}$ Langdon 1987: 15; Antonaccio 1994. $\quad{ }^{45}$ Whitley 1994: 217-18.
} 


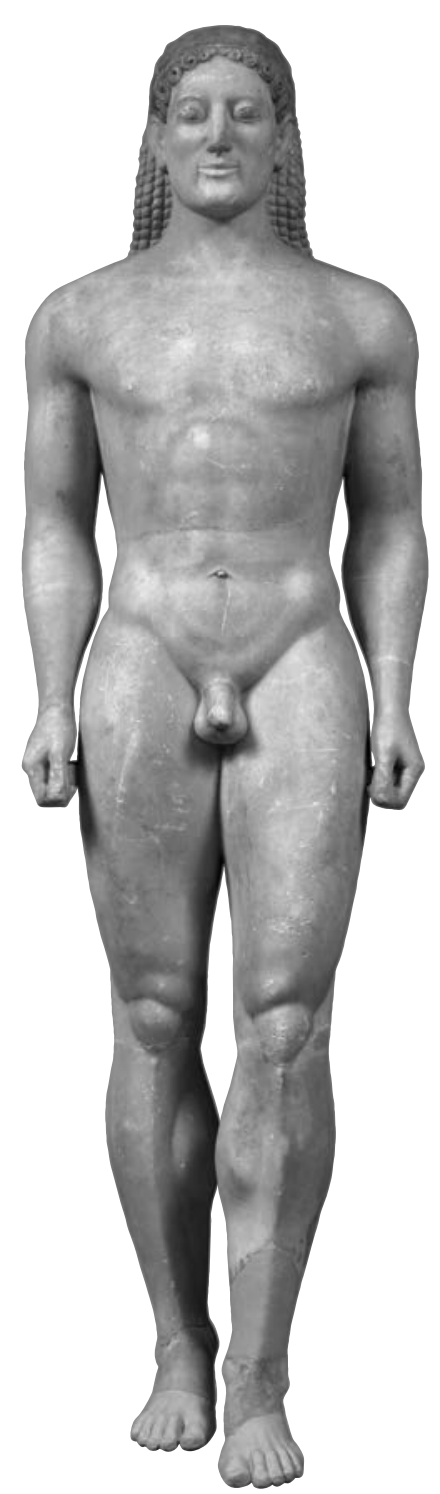

Figure 8.5 Croesus, Anavyssos kouros (NM Inv. 3851), c. 540 BCE. National Archaeological Museum Athens.

Egyptian models, became popular for representations of men, as votives in sanctuaries and funerary statues in cemeteries. Its popularity derived from the elitist iconography of an image equally appropriate for a man or a god, 
flattering the pretensions of an aristocracy whose prestige was partly based on privileged control over cults and claims of special propinquity to the gods. ${ }^{46}$ Like the memory objects of the Homeric poems, kouroi can be described as agalmata. ${ }^{47}$ An inscription on the base associated with one (Figure 8.5) reads: 'Halt and show pity beside the marker of dead Croesus, whom raging Ares once destroyed in the front rank of battle. ${ }^{48}$ Association with a group of similar statues, and grave tumuli which had been the site of elaborate tomb cult since the seventh century, suggest a long-standing family cemetery, probably of the Alcmaeonid clan. The name of the deceased - Croesus - is not Greek but Lydian, and points back to Alcmaeon, perhaps the grandfather of the deceased, who had been enriched by a relationship of guest friendship with Croesus, king of Lydia. ${ }^{49}$ The content and vocabulary of the epigram, with their heroic allusions, echo odes by poets like Pindar, celebrating the victories of aristocratic athletes in the festival games of the Greek world. ${ }^{50}$ Although an epigram offers little scope for elaborating ancestry, the name Croesus evokes distinguished genealogy and illustrious relations of inherited guestfriendship. Pindar's odes describe genealogies to a depth comparable with Zhou bronze inscriptions. The sixth Nemean ode celebrates Alcidamas of Aegina, winner of the boys' wrestling, as heir to a succession of athletic victors stretching back five generations (all individually named), the glory of the Bassidai clan, descendants of Heracles. Statues of ancestors, almost certainly kouroi given the date, ${ }^{51}$ could be the focal objects of ritual performance of such odes in their honorand's home town: the fifth Nemean celebrates the 'inherited destiny' (potmos syggenes), which brings Pythias to embellish (agallei) the lustre inherited from his ancestors, his uncle Euthymenes, also a Nemean victor, and his grandfather Themistios whose statue (agalma) in the sanctuary of the hero Aeacus is crowned with garlands and the victor's fillets as the closing gesture of the chorus performing the ode in celebration of Pythias' victory. ${ }^{52}$

In most victory odes the glory of athletic victory accrues also to the polis as a whole, but this does not indicate a radical opposition between the principles which informed the social construction of memory in archaic Greece and Zhou China: the inscriptions of Zhou bronzes show a similar

46 Stewart 1986. Aristocratic cult dominance: Parker 1996: 56-66 Athens; Tanner 2006: 57; Fearn 2010: 176 Aegina, 192 Thebes.

47 Karusos 1961; 1972: 93-102.

48 Hansen, Carmina epigraphica graeca saeculorum 27, trans. after Day 1989: 19.

49 Herodotus 6.125; Whitley 1994: 229; Neer 2011: 22-30. $\quad{ }^{50}$ Day 1989: 19.

51 Pausanias 8.40: kouros as athlete portrait.

52 Pindar, Nemean Ode 5.40. Mullen 1982: 143-64; Steiner 2001: 259-64. 
tendency in their expression of allegiance to the Zhou king, notwithstanding the disintegration of practical Zhou hegemony. The material forms in which the ancestralising memory practices of archaic Greek and Western Zhou aristocrats were realised have almost nothing in common, indebted rather to the specific histories of the two civilisations, based on continuities with Shang traditions in the Western Zhou, on cultural discontinuity and on renewed contacts with the civilisations and artistic traditions of the Eastern Mediterranean in the case of archaic Greece. Differences in social and political structure inflect these practices, performed in distinctive institutional settings: ancestral cults in temples open only to lineage members in China, ${ }^{53}$ linked to the larger Zhou polity by the rituals of investiture which bronzes also memorialised; the dedication of statues in cemeteries and sanctuaries, and their ritual appropriation as focus or frame for funerals and choric performances in the archaic Greek world, more open to the broader civic environment with which the elites of the small-scale city-states were required to engage. Notwithstanding these differences, the two cases are interestingly comparable in so far as the historical memory articulated in the verbal and visual arts of both archaic Greece and Western Zhou China was dominated by the ancestralising strategies of aristocratic elites, and had a strongly ritual and performative character, focused on prestige objects, rather than involving the picturing of history which developed later.

\section{Picturing History in Classical Athens}

The Persian Wars are often considered a turning point in historical selfconsciousness amongst the Greeks, particularly the Athenians who played a leading role in defeating the Persians at the battles of Marathon and Salamis. Two memorials of the wars indicate the changing role of visual art in the construction of historical memory, marking the transition from aristocratic traditions of the archaic period to a practice of picturing history informed by a more strongly civic and democratic ethos: the Marathon Monument at Delphi and the painting of the battle of Marathon in the Stoa Poikile in Athens.

Pausanias describes a statue group at Delphi celebrating Athenian victory at the battle of Marathon. ${ }^{54}$ It was erected in the 460 s BCE, instigated by the Athenian general Kimon, at the height of his influence in Athens

${ }^{53}$ Wu 1996: 8-10. $\quad{ }^{54}$ Pausanias 10.10.1. 


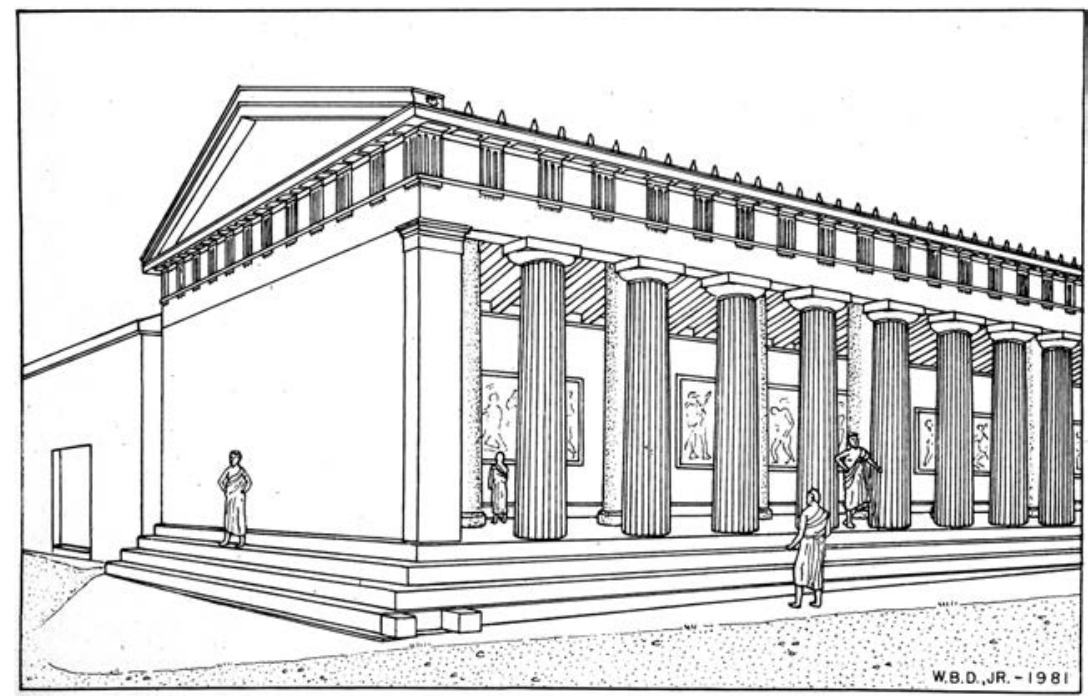

Figure 8.6 Stoa Poikile, Athens, c. 460 BCE. Restored perspective by W. B. Dinsmoor.

after victory over the Persians at the battle of Eurymedon. ${ }^{55}$ It showed Miltiades, Kimon's father, flanked by Apollo and Athena, and accompanied by a group of ten Attic heroes, some of them eponymous heroes of the Attic tribes, but with three substitutes - Kodros, Theseus and probably Philaios. The monument has been considered 'an expression of filial piety' on the part of Kimon, and is shaped by the same kind of ancestralising strategies as characterised archaic art and Pindar's poetry. ${ }^{56}$ It claims for Miltiades alone the victory at Marathon - he was in fact just one of the board of ten generals, and technically the command was that of the polemarch Callimachus - elevating him, a mortal, into the company of gods and heroes. The choice of Philaios amongst the substitute heroes alludes to Kimon's genealogy, as a member of the Philaid clan, descended from Zeus via the hero Ajax and his son Philaios. ${ }^{57}$

The paintings of the Stoa Poikile were also indebted to the initiative of Kimon and his family (Figure 8.6). The Stoa was originally known as the Peisianakteion, named after Peisianax, the brother-in-law of Kimon, who presumably provided some of the funds for its construction, in the late 460 s. $^{58}$ But stories concerning the development of the iconography, the labelling and the composition of the painting all indicate the increasingly tight democratic control of civic art characteristic of classical Athens. ${ }^{59}$

\footnotetext{
55 Harrison 1996: 23-8. ${ }^{56}$ Castriota 1992: 81. ${ }^{57}$ Connor 1970: 164.

58 Stansbury O’Donnell 2005: 81. ${ }^{59}$ Rouveret 1987/9: 103.
} 


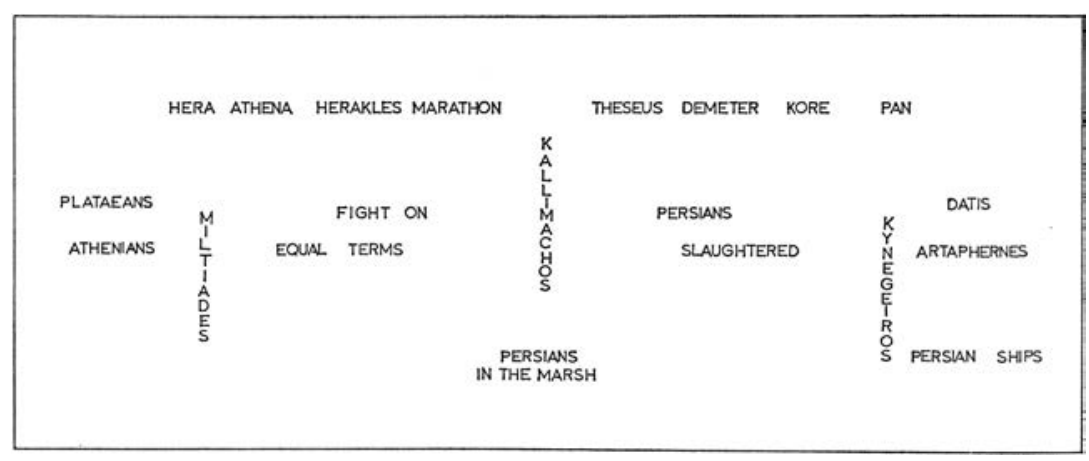

Figure 8.7 Reconstruction of compositional scheme of the Battle of Marathon Painting in the Stoa Poikile.

Correspondingly, the character of the paintings is sometimes held to be a democratic response to the elitist and ancestralising claims of the Delphi statue group, shaped by the radical democratic reforms of Ephialtes which marked the eclipse of Kimon's influence. ${ }^{60}$ A request that Miltiades, alone amongst the protagonists, be identified by an inscription stating that he had led the Athenians to victory was refused - the victory was of all Athenians, not of one man alone - although it was granted that Miltiades be shown in the forefront, urging on the soldiers. ${ }^{61}$ An experimental perspective effect by Mikon, showing some Greeks in the background smaller than Persians in the foreground - and misread as a demeaning representation, since lower-status figures were conventionally represented smaller than higher-status figures - earned the painter a fine of thirty minas. $^{62}$

Although the painting no longer survives, we can reconstruct some key features from ancient descriptions (Figure 8.7). ${ }^{63}$ At the left, the painting showed the Athenians and Plataeans, drawn up in battle line on the slopes above the plain: Miltiades gives the signal committing them to battle. Immediately to the right were the forces of the two armies meeting on the plain, broken up into individual duels, and culminating in the heroic death of the polemarch Callimachus at the centre of the painting. This represents the turning point of the battle: the Persians are driven back to the marshes at the edge of the plain, and then in headlong flight towards their ships. Here, at the extreme right, the last iconic scene of the battle was depicted: Kynegeiros grasps the bowsprit of one of the Persian ships,

\footnotetext{
${ }^{60}$ Harrison 1996: 26. ${ }^{61}$ Aeschines 3.186. ${ }^{62}$ Reinach 1921, no. 141.

63 Pausanias 1.15; Harrison 1972; Hölscher 1973: 50-84; Stansbury O’Donnell 2005.
} 
attempting to prevent the flight of the Persian commanders Datis and Artaphernes, only to fall to the blow of a Persian axe which lops off his arm. The top register of the painting included representations of deities and heroes - Athena, Theseus, Heracles - who were held to have been present, and supportive, at the battle, though they were not depicted as actually taking part in it. Two smaller paintings, pendants to the Marathon painting, showed the Sack of Troy and an Amazonomachy.

Contemporary vase-painting, and later relief sculpture, allow us to visualise aspects of the Marathon painting. Depictions of Greeks fighting Persians in vase-paintings, and especially the increasingly realistic and detailed representation of their weapons, reflect the historical turn in contemporary painting, contrasting with the epic-mythological character of warfare in earlier black-figure vases. ${ }^{64}$ Persians are sometimes depicted already on the run, as they turn to face their Greek pursuers, emphasising the effeminate propensity to flight of the Persians, described in contemporary texts and encoded in the structure of the Marathon narrative (Figure 8.8). ${ }^{65}$ Harrison argues that the south frieze of the temple of Athena Nike represents the battle of Marathon and is modelled on the Poikile paintings. One section (Figure 8.9) shows a Greek warrior delivering the coup de grâce to a Persian. The Greek is naked, himation falling around his knees (a conventional heroic motif), his right arm raised up to deliver the mortal blow to his Persian adversary. His left arm swings away from his body, leaving him vulnerable, echoing in detail the posture of Harmodios from the Tyrannicide group (Figure 8.1). This was a deliberate choice, informed by the same account of the battle of Marathon as that Herodotus. At the end of a debate between the Athenian generals whether to attack the Persians immediately, before their army is fully disembarked, or to wait for assistance from the Spartans, Miltiades, advocating immediate attack, addresses Callimachus, the polemarch with whom the final decision lies: 'Callimachus. It is up to you either to enslave Athens or to make her free and leave for yourself a memory such as neither Harmodios nor Aristogeiton left. ${ }^{\prime 66}$ The tyrannicide-like figure on the frieze is Callimachus, at the moment of his aristeia, as depicted at the centre of the painting of the battle of Marathon in the Stoa Poikile. ${ }^{67}$ The Persians are fully clothed, in tunic and trousers, a touch on the corpulent side, and sluggish in their movement. ${ }^{68}$ The Athenians, contrastingly, manifest an ideal and elevating nudity. Their muscled bodies and striking postures

\footnotetext{
${ }^{64}$ Csapo and Miller 1998: 116-17. ${ }^{65}$ Castriota 1992: 83-4. ${ }^{66}$ Herodotus 6.109.

67 Harrison 1972: $355 . \quad{ }^{68}$ Stewart 1985: 62.
} 


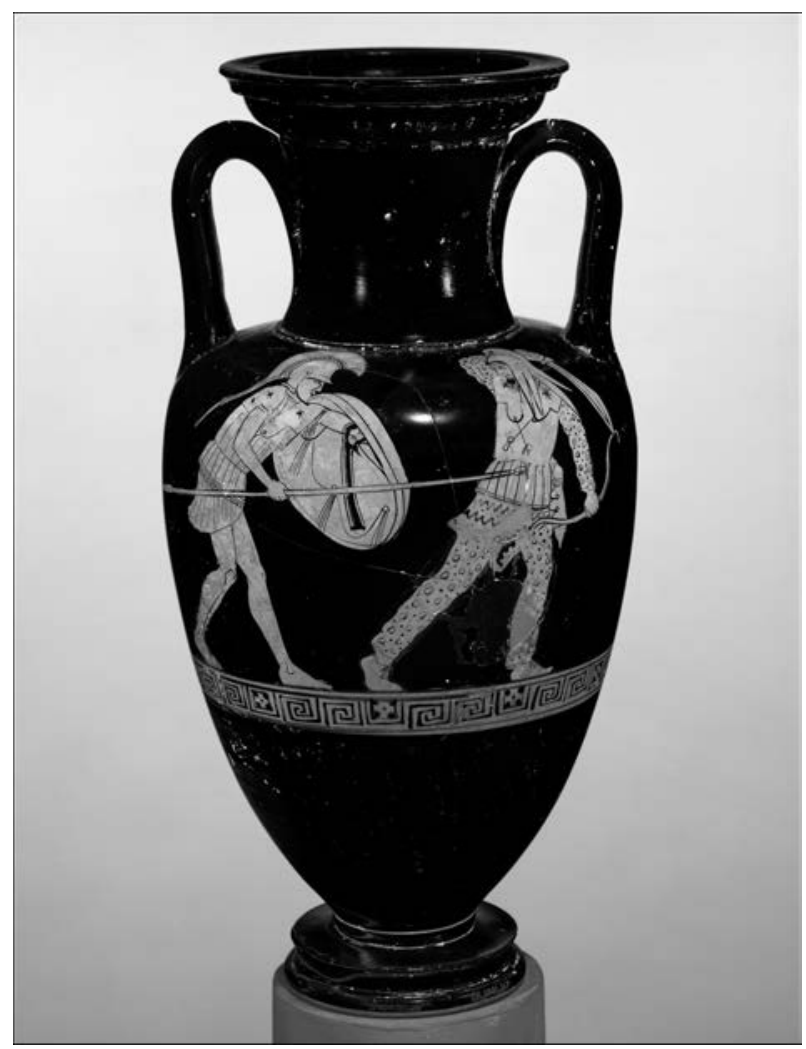

Figure 8.8 Greek battles fleeing Persian. Attic red-figure Nolan amphora. New York, Metropolitan Museum of Art.

embody an ethos which was held to be characteristic of the men of Marathon, and their descendants, ready 'to use their bodies as if they were those of other men, when it is in the service of their city ... to accomplish anything on her behalf. ${ }^{69}$ The figure of Callimachus evokes the concept of the beautiful death, informed by a positive decision to sacrifice one's own life on behalf of the polis. ${ }^{70}$

The juxtaposition of mythical and contemporary events, and the elaboration of the meaning of the latter through analogies with the former, were a convention of epinician poetry like that of Pindar, celebrating individual athletic victors. Extended to civic history in Simonides' poem on the battle of Plataea, it also characterises inscribed herms celebrating the victory of Kimon and the Athenians at Eion. ${ }^{71}$ Framing the Marathon painting with an Amazonomachy and Ilioupersis, and presenting it in

69 Thucydides 1.70. $\quad{ }^{70}$ Loraux 1986: 98-118. ${ }^{71}$ Boedecker 1998: 190; Aeschines 3.183. 


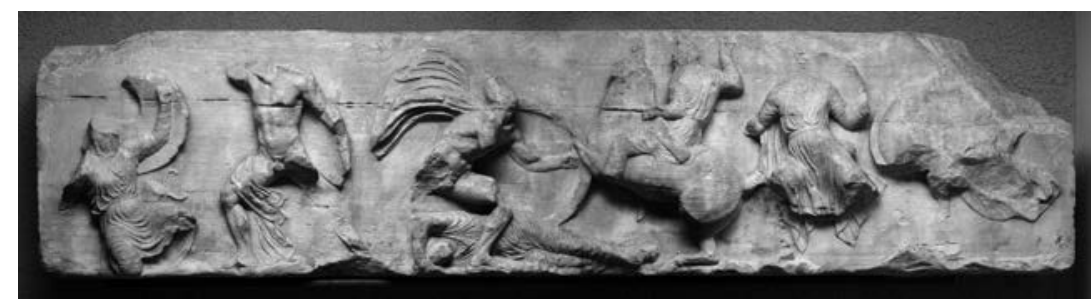

Figure 8.9 South frieze from the Temple of Athena Nike, Athens. Slab G, British Museum.

terms of value-laden iconographic codes, gave specific ideological inflection to the depiction of history. The battle was given a pedigree in deep time, similar to that in Herodotus who attributes the origins of the enmity between the Greeks and the Persians to the rape of Helen and the sack of Troy. ${ }^{72}$ The Amazonomachy paralleled the defensive character of the Athenians' struggle against the Persians, since Theseus' heroic battle against the Amazons had taken place in Athens itself, in the immediate environs of the Acropolis, where the sites of the Amazon encampments could still be pointed out. ${ }^{73}$ Most importantly, as the Tyrannicide imagery implied, the battle of Marathon was fought for freedom. ${ }^{74}$ Further resonance derived from the contemporary use of Tyrannicide iconography for representations of Theseus, mythical founder of Athenian democracy, punishing violators of moral order in his cycle of deeds. ${ }^{75}$ The courage of the Athenians in the protection of freedom at Marathon thus appears as the expression of an intrinsic virtue, rooted in time immemorial.

This artistic programme was elaborated during the following halfcentury to provide a strongly affirmative, but increasingly tendentious and ideological, account of the history of Athens, not only in the Persian Wars, but also in those of the later fifth century. Another painting was added to the Stoa Poikile, showing a battle at Oinoe, between the Athenians and the Spartans, at the beginning of the Peloponnesian War. ${ }^{76}$ In 425 BCE, the Stoa was decorated with shields captured from the Spartans at Sphacteria. Painting and shields alike added a new layer of meaning to the existing programme, legitimating the wars against Sparta and her allies as a continuation of, and congruent in their character with, the great struggles of earlier, historical and mythical, eras. ${ }^{77}$ The late fifth-century wars, however, were fought not against Persians, but against other Greeks, in

72 Herodotus 1.3-4. ${ }^{73}$ Connor 1970: 157; Plutarch, Theseus 27.

${ }^{74}$ Harrison 1972: 362; Castriota 1992: 79-80. ${ }^{75}$ Henle 1973: 80-2. ${ }^{76}$ Taylor 1998.

77 Stansbury-O’Donnell 2005: 80. 
defence less of Greek liberty than Athens' freedom to control and exploit the dependent cities of an empire which she had established following the Persian Wars.

The increasingly ideological character of Athenian historical representation is highlighted by the Temple of Athena Nike. This temple was likely built with the fruits of Athenian victories in the first phase of the Peloponnesian War, and possibly also with allied tribute money. It was constructed in the mid-420s BCE, and a priestess installed in 423, shortly after the annual payments of Athens' allies had been reassessed to include symbolic tribute of arms and cattle to be presented to Athena at the annual Panathenaic festival. This was part of the muscular imperialism associated with the leadership of Cleon. It is no coincidence that the bastion on which the temple stood was decorated with shields captured by Cleon in his great triumph over the Spartans at Pylos and Sphacteria. ${ }^{78}$ The south frieze, depicting Marathon, was juxtaposed with two further scenes of warfare. The west frieze is thought to represent a contemporary battle, perhaps Sphacteria or an Athenian victory in north-western Greece during the first phase of the Peloponnesian War. ${ }^{79}$ The north frieze depicts the slaying of Eurystheus. After the death of Heracles, his children fled the Peloponnese for Athens, pursued by their father's persecutor King Eurystheus, who sought to enslave them. They begged sanctuary with the Athenians, who refused to give them up to Eurystheus, who had invaded Attica in their pursuit, with an army from the Peloponnese. ${ }^{80}$ Athenian support for the Heracleidai had been invoked as early as the battle of Plataea (479 BCE), as one of the grounds for the Athenian claim to a privileged position in the Greek battle line against the Persians: it revealed the exceptional piety and compassion of the Athenians - they alone amongst the Greeks had offered the Heracleidai sanctuary - as well as their unrivalled virtue as defenders of freedom and punishers of hubris. ${ }^{81}$ The message of the programme of the temple of Athena Nike is clear: all Athens' wars, even those against other Greeks, are defensive wars; she intervenes only in order to punish the lawless, to protect the weak and liberate the enslaved, all in a spirit of compassion and self-sacrifice. ${ }^{82}$

Combining myth with history to celebrate the arete of Athens, the programmes of the Stoa Poikile and the Temple of Athena Nike parallel the topoi of the Funeral Orations, delivered annually at the burial of the Athenian war dead. Here too the Amazonomachy and the rescue of the

\footnotetext{
${ }^{78}$ Lippmann, Scahill and Schultz 2006: 559. ${ }^{79}$ Stewart 1985; Schultz 2009: 130, 150

${ }^{80}$ Schultz 2009: 142-6. $\quad{ }^{81}$ Loraux 1986: 67. ${ }^{82}$ Stewart 1985; Schultz 2009.
} 
Heracleidai are invoked as paradigms of Athenian virtue, and the loss of the war dead redeemed for posterity as 'beautiful deaths', willing sacrifices on behalf of the city. ${ }^{83}$ This rhetorical tradition indicates the cultural and institutional horizons in terms of which these picturings of history were appropriated by Athenian viewers. In Plato's Menexenus, Socrates describes the effect that hearing the funeral oration has on him: he feels himself 'mightily ennobled', and imagines himself to have become 'at once taller, nobler and more handsome', as he seems also in the eyes of foreign friends who accompany him, a feeling which lasts for several days. ${ }^{84}$ Describing the 'bewitching' effect (goèteia) of the funeral oration, Socrates insists on the visual as the medium in which the glorious deeds of the Athenians and their ancestors are best grasped. ${ }^{85}$ Considering the arete $\bar{e}$ of the generation of Marathon, 'it is necessary to visualise it (idein), if we are to praise it fitly, placing ourselves in thought in that very time, when the whole of Asia was already in bondage to the third of the Persian kings' ${ }^{86}$ In evoking the achievements of that epoch, and their inspirational character, Socrates seems to describe a visual experience, like looking at a painting of the battle of Marathon (which, like other monuments, might be described as an ergon): 'I affirm that those men were the begetters not only of our bodies, but also of our freedom; for it was with their eyes fixed (apoblepsantes) on this great work (ergon) that the Greeks dared to risk the battles joined in later times for their salvation, learning the lessons of the men of Marathon. ${ }^{, 87}$

Athenian rhetoric transforms myth and history into visual, even visionary, experience, appropriated as an ethical model to shape the actions of a citizen audience. The fourth-century orator Lycurgus praises the dramatist Euripides for staging the story of the Attic king Erechtheus and his family, saving the city from a Thracian invasion, in one of his plays, 'considering that the finest example (paradeigma) to offer the citizens is the heroic acts of former times: they have only to look at (apoblepontas) them, and contemplate (theōrountas) them to cultivate love of country in their hearts'. ${ }^{88}$ In other speeches the Marathon paintings themselves are invoked for jurors to envision them in their mind's eye (dianoia), as the source of exemplars against which to judge the character and contributions of later benefactors of the city. ${ }^{89}$ As described in the Menexenus, these visions are 'theoric': the viewer is presented with a vision which is the object of wonder

\footnotetext{
${ }^{83}$ Loraux 1986. $\quad{ }^{84}$ 235e; Porter 2011: 66.

${ }^{85}$ Goèteia is used by Gorgias and Plato to describe the powers of painting and rhetoric alike.

${ }^{86}$ Menexenus 239d, trans. Loeb. ${ }^{87}$ Menexenus 240e.

${ }^{88}$ Lycurgus, Leocrates 100; Loraux 1986: 136. $\quad{ }^{89}$ Aeschines 3.187; Demosthenes 59.94.
} 
and reverence, a religious spectacle of transcendent beauty. Similarly, Thucydides has Pericles, in the first funeral oration of the Peloponnesian War, instruct his audience 'to gaze (theōmenous) on the power of the city day after day, becoming her lovers' ${ }^{90}$ Just such an enduring vision of Athens' power was offered both in the Marathon programme of the Stoa Poikile and in the depictions of history on the temple of Athena Nike, raised high on its bastion, glistening with shields of Athens' defeated opponents (Figure $8.10 \mathrm{a}-\mathrm{b}) .{ }^{91}$ Pictured history was a vehicle for affective identification with the manifest destiny of Athens: it recompensed the dead, comforted the bereaved and encouraged the living, 'appealing to their children and their brothers to imitate the arete of these men'. ${ }^{92}$

\section{Picturing History in Early Imperial China}

There is sufficient interest in the pictorialisation of history in early China to refute any claims of an essential difference between the two traditions, as opposed to the differential elaboration of shared cultural possibilities. Contributions to the military successes of the Zhou are amongst the achievements commemorated and rewarded in the ritual bronzes of the Western Zhou, and warfare is a central theme of the pictorial bronzes of the Warring States (So 1980a). Furthermore, there are depictions of battles between Han Chinese and foreign (nomadic) barbarians in Han funerary art, mostly of a rather generic character. One which may be intended to depict a particular historical event is that on the Xiaotangshan shrine, where - amidst scenes of battle, and decapitation of prisoners - one of the figures is specifically named as 'Hu Wang', the King of the Hu (barbarians). This is by some margin the largest surviving Han shrine, and such an unusual example that it has been suggested that it was dedicated to a prince of the ruling dynasty, perhaps the brother of Emperor He, rather than a member of the shi. ${ }^{93}$

Depictions of specific historical battles, however, seem very unusual in Han art. A story in the History of the Former Han tells of a Chinese commander commissioning paintings of a campaign in Central Asia, including the siege of a fortified city of the Xiongnu. On his return to the capital, the victories were reported to the High Gods and the Imperial Ancestors, before the paintings were ultimately displayed at a celebratory

\footnotetext{
90 Thucydides 2.43; Stewart 1997: 83 (trans). ${ }^{91}$ Nightingale 2001. ${ }^{92}$ Menexenus 236e.

93 Soper 1974; James 1988/9.
} 


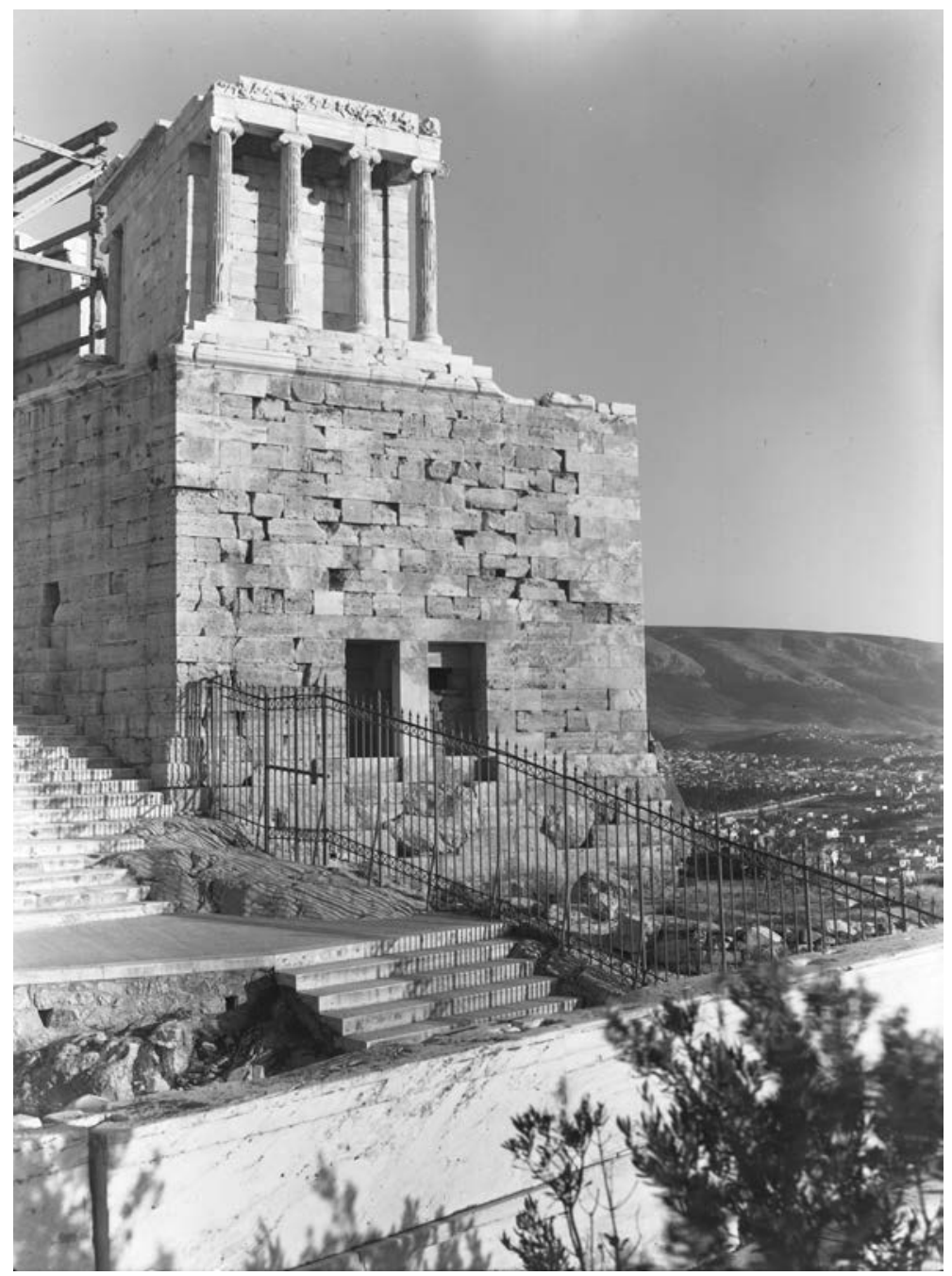

Figure 8.10 (a) Temple of Athena Nike, Athens, c. 425 BCE.

banquet in the imperial palace. Three comments are worth making. First, the paintings seem to have had a rather exceptional motivation: the commander in question had forged an imperial edict in order to mobilise the troops necessary for the expedition, and the paintings seem to have functioned as part of a publicity campaign to save his neck. Second, the incentive for the emperor to translate such paintings into some kind of monumental memorial was rather limited, since, unlike his Roman counterparts, for example, he played no personal role in military campaigns. 


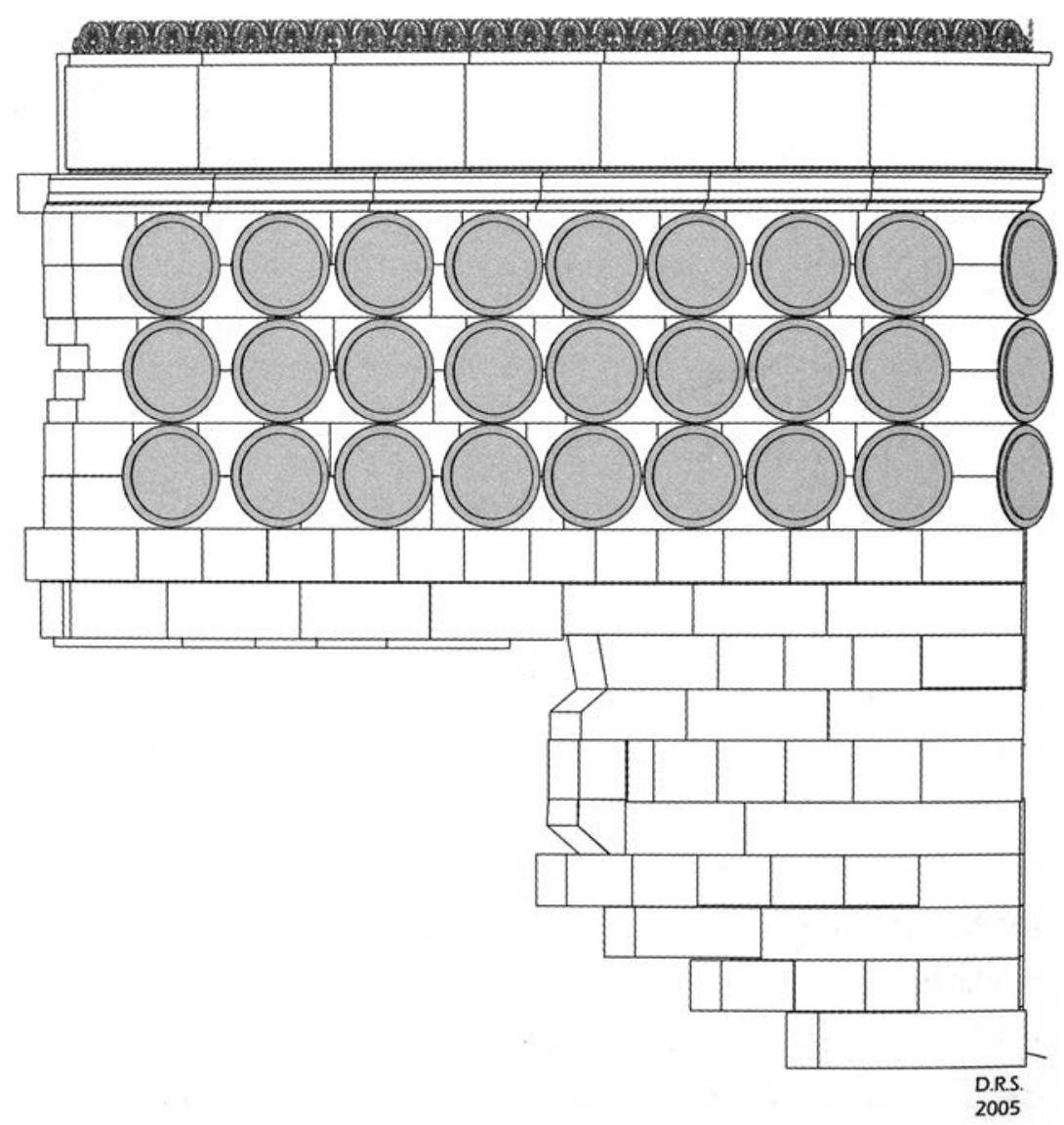

Figure 8.10 (b) Reconstruction of bastion of the Temple of Athena Nike, with shields attached. Drawing: David Scahill.

Third, it is symptomatic of the status of such paintings that an important part of their interest for the historian Ban Gu was that the scenes of women warriors in Central Asia were so striking that the paintings were even circulated amongst the ladies of the imperial harem, for their amusement. ${ }^{94}$ This is not to say that there was no monumental art of a historical character oriented to the celebration of military victory in Han China, only that it was not as institutionally central as in classical Greece or ancient Rome. ${ }^{95}$

94 Duyvendak 1939/40; Barbieri-Low 2007: 173-7. Such paintings are so unusual in their character that Duyvendak attributes them to the influence of Roman soldiers and artisans who may have been present in the Xiongnu city.

95 The tomb of the great general Huo Qubing (d. 117 BCE), constructed within the imperial funerary park on the instructions of Han Wudi, included a tumulus modelled on a mountain 
The picturing of history in early imperial China developed in a different direction. A prose poem by Wang Wenkao (second century CE) describes the decoration of the 'Hall of Numinous Brilliance', built by the Han King, Liu Yu, King Gong of $\mathrm{Lu}$ in the mid-second century BCE. Amongst elaborate carvings of prowling tigers and leaping dragons, enriching the columns and rafters of the hall, the poet describes a programme of wallpaintings, recording the history of the world from its beginnings - 'Above they record the Opening of Chaos,/The beginnings of remote antiquity' through the (mythological) Nine Sovereigns, to stories of more recent times: 'Last come the Three Sovereigns,/Depraved consorts, misguided rulers,/Loyal statesmen, filial sons,/virtuous shi, chaste women,/Worthies and fools, the failed and accomplished,/None have gone unattested./The wicked are warnings to the world,/The good are examples for posterity.'96 Wang Wenkao's vocabulary echoes that of history writing, indicating that he viewed the paintings as pictorial records of the past parallel to those transmitted in texts by royal scribes and annalists. Representing the story of the world as a unified whole from the remote past of legendary rulers like the Yellow Emperor, through the rulers of the Xia, Shang and Zhou dynasties, to loyal ministers, and then stories of ordinary men and women, memorable for their filial piety or virtue, these paintings remarkably anticipate both Sima Qian's Shiji, written at least a generation later and structured along similar lines, and the most famous and systematic pictorialisation of history in early China, the engravings of the $\mathrm{Wu}$ Liang Shrine (mid-second century CE).

Like the Numinous Hall, the pictures of the $\mathrm{Wu}$ Liang Shrine present a universal history embedded within a cosmic frame. ${ }^{97}$ The frame is provided by depictions of omens on the ceiling, and of the deities the Queen Mother of the West and the King Father of the East and their realms in the gables of the west and east walls. ${ }^{98}$ The remainder of the three walls of the shrine reads, like a Chinese text, from right to left and from top to bottom (Figure 8.2). It starts on the upper row with Fuxi and Nuwa, the creators of mankind, followed by the Nine Sovereigns, and Jie, the last king of the Xia (2000-1600 BCE), whose shortcomings led to the fall of the dynasty, and its replacement by the Shang (1600-1400 BCE). There follows - upper row, back and left walls - a series of representations of famous women of the Eastern Zhou (771-256 BCE). The second register has depictions of

\footnotetext{
that had been the site of one of Huo's victories, as well as an expansive programme of sculpture: horses trampling barbarians, and various animals and monsters - Paludan 1991: 17-27.

96 160-8; Knechtges 1987: 275. ${ }^{97}$ Croissant 1964; James 1988/9; Wu 1989.

98 Wu 1989: 73-141.
} 
stories from the lives of famous men, mainly filial sons, but also exemplary brothers and friends, starting with figures from the Zhou, and culminating with a filial son of the Eastern Han (25-220 CE), who had died not long before the construction of the shrine. The directional sequence of the figures - all facing right - emphasises movement in historical time. ${ }^{99}$ The central panel of the lower half of the walls shows a large columned pavilion, in which homage is being paid to the deceased. This is flanked by stories of notables of Eastern Zhou history: six assassin retainers, including Jing Ke's attempted assassination of the King of Qin, later the First Emperor; distinguished ministers, Lin Xiangru and Fan Sui; and Zhongli Chun, an ugly woman nevertheless valued as an adviser by King Xuan of Qi. The larger theme informing the whole programme, Wu Hung argues, is the patterning of history, shaped by the Three Bonds of Confucian morality - the ruler-subject relationship, parent-son, husband-wife - within the context of a correlative cosmology in which Heaven-sent omens respond to the moral status of the empire. ${ }^{100}$ This concept of history is informed by Sima Qian's Shiji, and, like Sima Qian, Wu Liang depicts himself at the end of the history, as its recorder, in the final scene of the shrine, at the bottom left-hand extreme of the east wall. ${ }^{101}$ This systematic appropriation of history constitutes the shrine as a well-ordered universe for the hun-soul of the deceased, and offers a vision of righteousness and faithfulness to his descendants.

The Wu Liang Shrine is, however, not fully representative of the general character of the pictorialisation of history in Han art. Far more common are much smaller shrines, with no more than a couple of historical pictures, lacking the systematic programme which allows $\mathrm{Wu}$ Hung to trace the $\mathrm{Wu}$ Liang carvings to the same horizon of historical consciousness as that of the Shiji. One of the Song Shan shrines, for example, has just two historical pictures - Two Peaches and Three Warriors, and Ji Zha dedicating his sword at the tomb of the Lord of Xu (Figure 8.11a-b) - amongst a series of engravings dominated by standard elements drawn from the broader repertoire of funerary iconography (chariot procession, Queen Mother of the West, King Father of the East, the standard 'homage scene', and a kitchen scene). ${ }^{102}$ Even the largest surviving shrine, the Xiaotangshan Shrine, includes only a small selection of historical scenes - King Cheng and the Duke of Zhou, the First Emperor and the Loss of the Zhou Tripods,

\footnotetext{
99 Wu 1989: 143-4. ${ }^{100} \mathrm{Wu}$ 1989: 218-30. ${ }^{101} \mathrm{Wu}$ 1989: 213-17.

102 Ruitenbeek 2002: 40-5.
} 


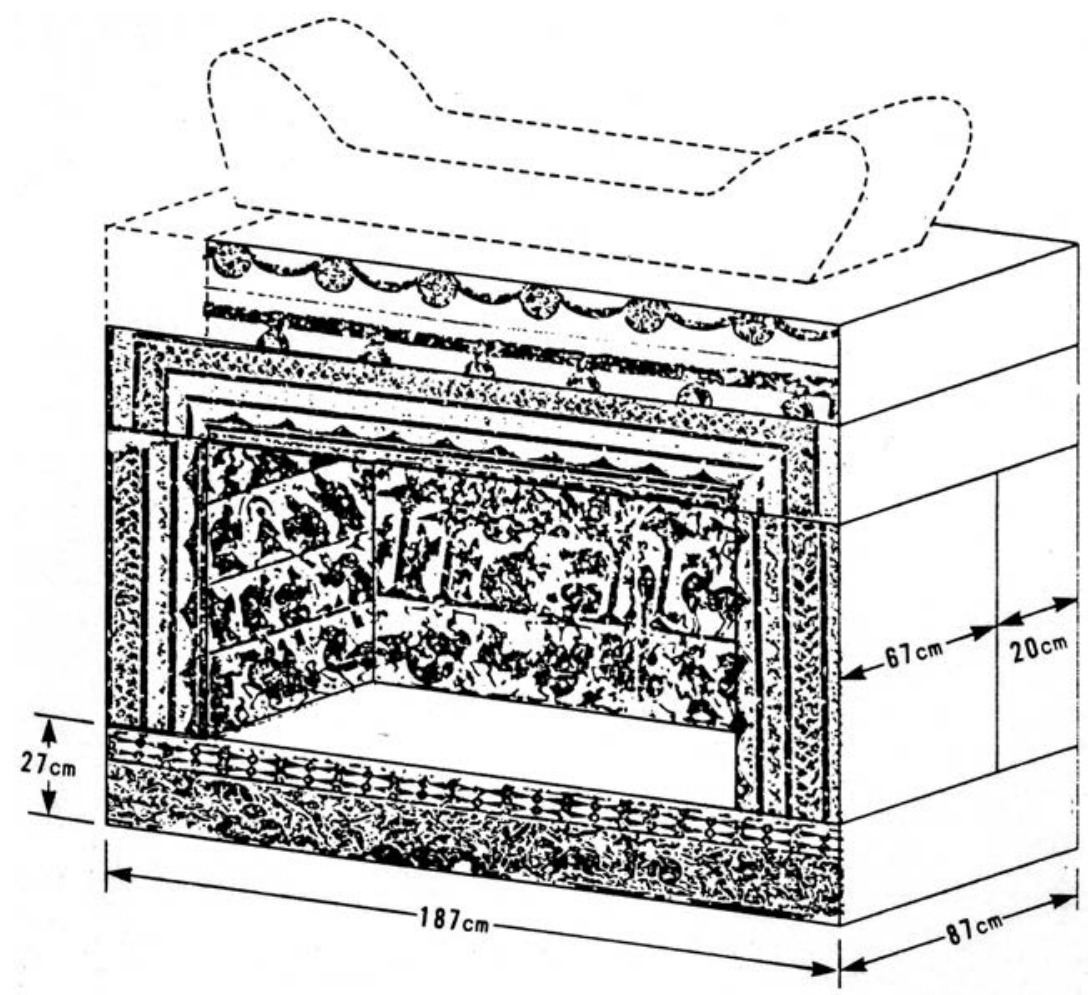

Figure 8.11 (a) Reconstruction of shrine from Songshan, second century CE.

and a battle with the Hu barbarians - amongst the more generic repertoire. The picture is complicated by the fact that many of the depictions from tombs and shrines survive only as isolated slabs, sometimes recycled in later tombs, and do not lend themselves to reconstruction as integrated monuments so easily as the Songshan shrines.

The impression emerges that individual tomb-designers selected, from a larger repertoire, a handful of sometimes rather disparate narratives that somehow resonated with the specific concerns of the sponsor of the tomb or shrine in question. It is this broader practice of the pictorialisation of history which is my focus. Rather than looking at specific programmes in individual tombs or shrines, it may be fruitful to examine some of the historical scenes which prove particularly popular, recurring frequently in the corpus of funerary art, especially of the Eastern Han, from which the bulk of the evidence dates: the story of Jing Ke's attempted assassination of the King of Qin (Figure 8.12), King Cheng and the Duke of Zhou (Figure 8.13), Two Peaches and Three Warriors (Figure 8.11b), and the 


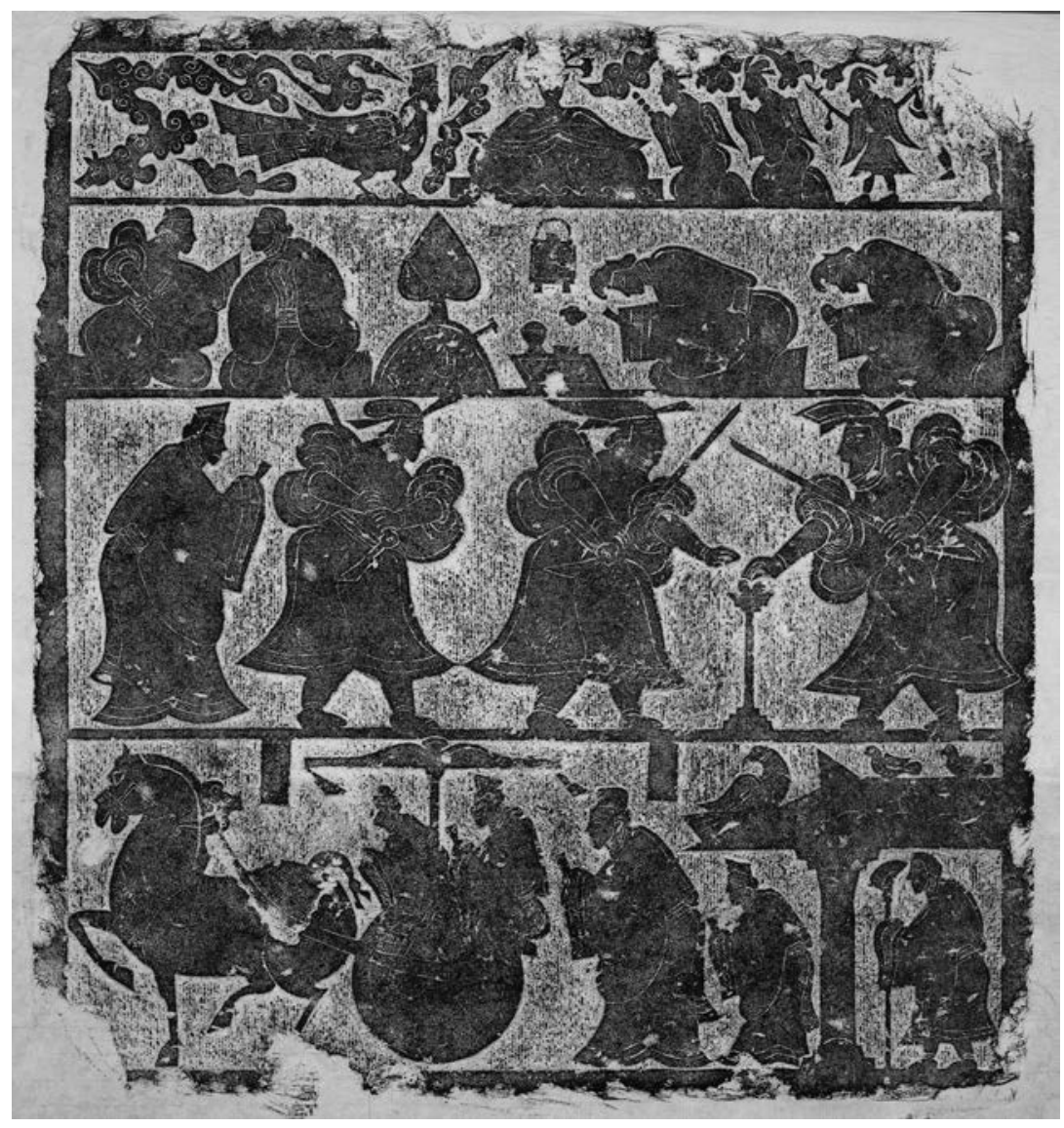

Figure 8.11 (b) West wall of shrine from Songshan, second century CE. Rubbing after engraved stones in Shandong Provincial Museum. Top: Queen Mother of the West. Second register: Ji Zha dedicates his sword to the Lord of Xu. Third register: Two Peaches and Three Warriors. Fourth register: Departure of chariot procession.

First Emperor and the Loss of the Tripods of Zhou (Figure 8.14). How can we understand the process by which these scenes were selected, and the special resonance that these particular historical events seem to have had for the producers and viewers of funerary engravings in the Eastern Han?

Wu Hung's study of the Wu Liang Shrine offers some initial clues. The shrine's programme was indebted to traditions of textual production characteristic of the shi, the literate elite from whose ranks the officials of the imperial bureaucracy were drawn, and who were the primary sponsors of the tombs and shrines decorated with these historical pictures. ${ }^{103}$

103 Status of tomb patrons: Thompson 1998: 105-37, esp. 128-37; 1999: 6-9. 


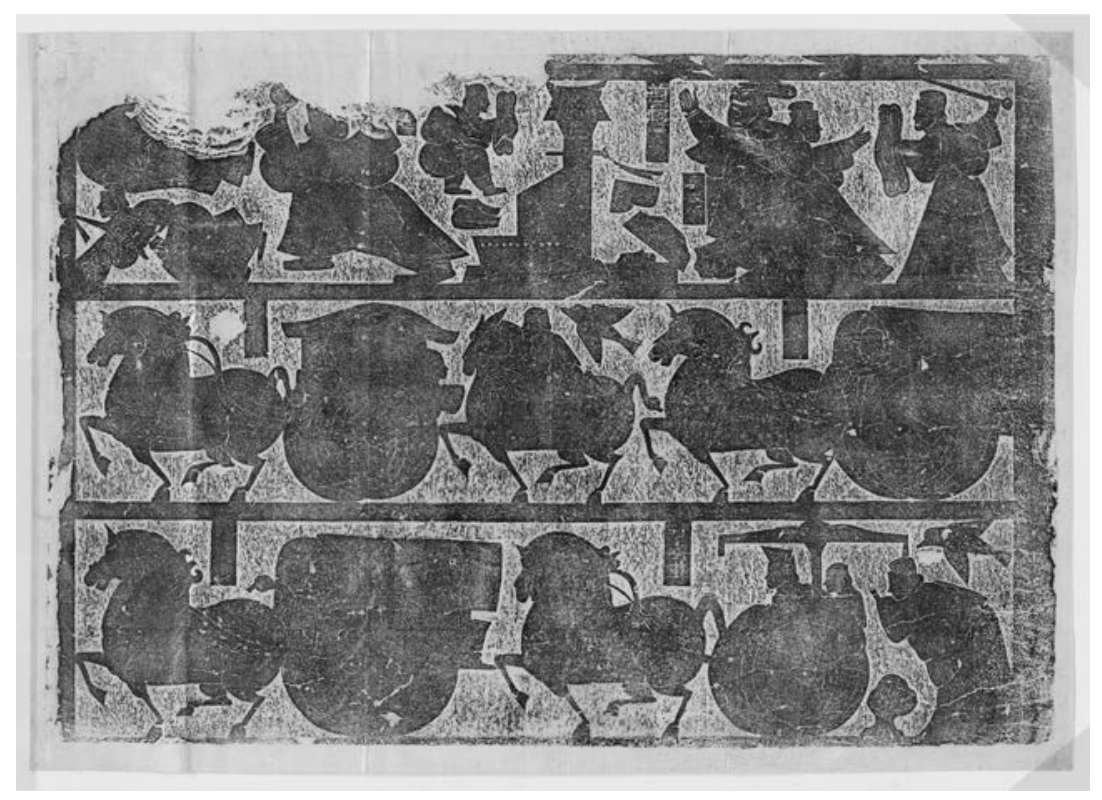

Figure 8.12 Jing Ke and the King of Qin (top register). Rubbing after engravings on the south wall of Shrine 1, Wu Family Cemetery. Second century CE.

Although Sima Qian's Shiji provided the 'organizational principles' for the Wu Liang Shrine, ${ }^{104}$ a number of other texts, and authors, seem also to have been important to its design, most notably Liu Xiang (79-78 BCE), a Counsellor of the Palace in the Western Han, and a major figure in the collation and editing of inherited classical texts. ${ }^{105}$ Liu Xiang was responsible for the compilation of the 'Stratagems of the Warring States', a collection of anecdotes about the intrigues which had informed the relations between the Warring States. Although today an important source for Warring States history, it is not so much a history or chronicle as a manual of examples, for practical and rhetorical use. ${ }^{106}$ Liu Xiang also assembled more focused compilations, including the Shuoyuan (Garden of Discourse). This collects stories in twenty chapters, some of which are miscellanies $(z a)$, while others have a specific political focus ${ }^{107}$ and even touch on some of the same stories as recur in funerary art. The chapter 'The Way of the Minister' includes the story of Lin Xiangru and the precious jade, one of the more popular themes in Han funerary art, demonstrating the moral integrity, the ingenuity and the readiness for self-sacrifice of the ideal

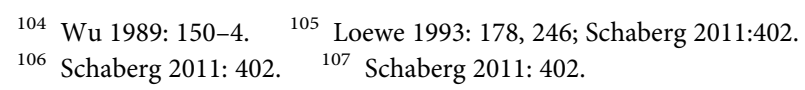




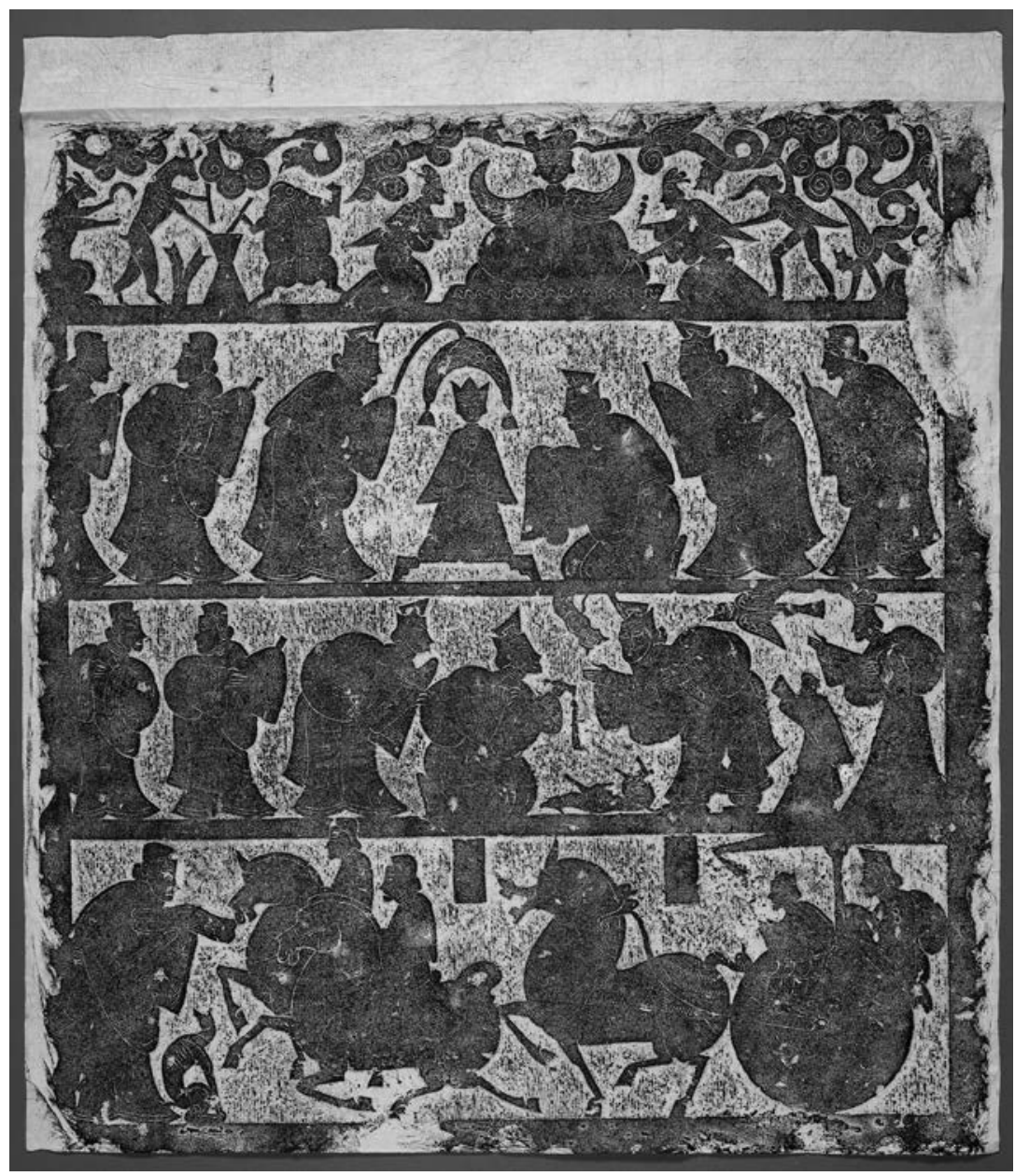

Figure 8.13 Rubbing after engraving from Eastern Han shrine, Songshan, Shandong Province. Top register: Queen Mother of the West. Second register: King Cheng and the Duke of Zhou. Third register: Liji and the death of Shen Sheng. Fourth register: Chariot procession and reception.

minister. ${ }^{108}$ 'Commissions' (fengshi) includes a series of assassin-retainers, like Jing Ke, exemplifying relations of righteousness and faithfulness between a ruler and a subject whom the ruler is able to persuade to undertake the commission. ${ }^{109}$ Some of Liu Xiang's compilations had very specific scope, occasioned by particular circumstances at court. The Lienü Zhuan (Arrayed Biographies of Women) was designed to enhance

108 Wu 1989: 188-90, 305-8; Thompson 1999: 17; Finsterbusch I.319, 3.A83, A84.

109 Wu 1989: 188-91. 


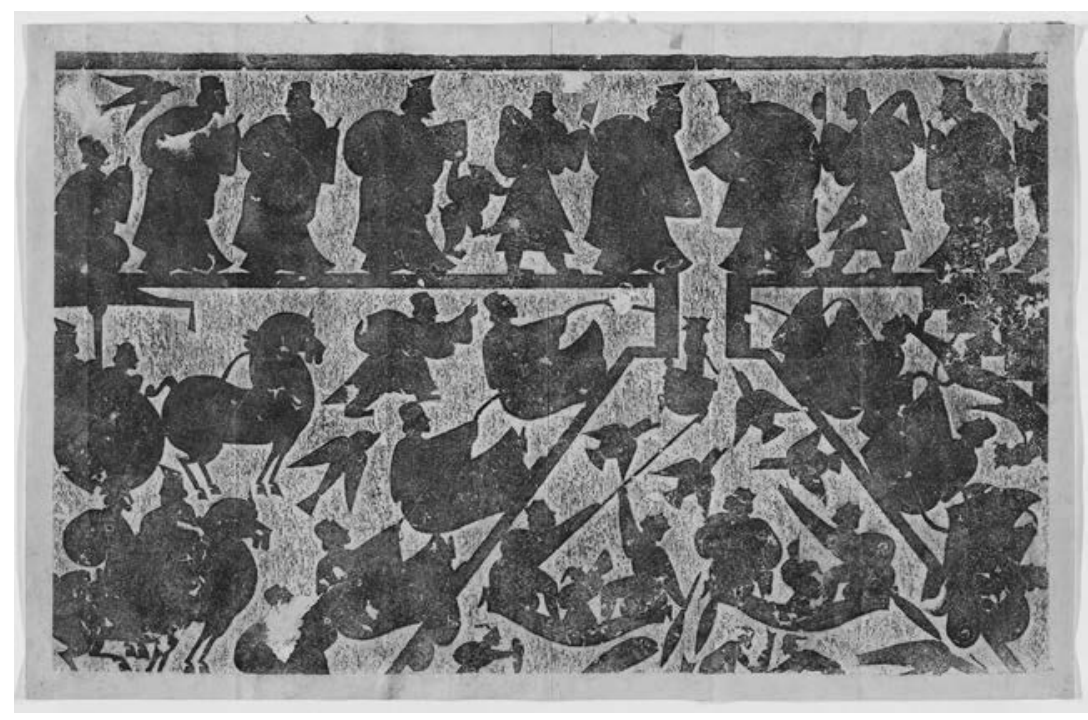

Figure 8.14 The First Emperor fails to recover the Zhou Tripods. Rubbing after engravings on the East Wall, Chamber 2, Wu Family Cemetery, Shandong.

standards of moral conduct at the court, in the wake of Emperor Cheng's infatuation with and indulgence of the Zhao sisters, ${ }^{110}$ and a broadly similar purpose must have informed the 'Arrayed Biographies of Filial Sons'. The specific selections of images of virtuous women and filial sons on the Wu Liang Shrine seem to imply dependence on Liu Xiang's compilations as a source of inspiration. ${ }^{111}$

Liu Xiang's writings represent one important instance of a much broader phenomenon of the textualisation of authority, well under way in Warring States China, and institutionalised in early imperial China. ${ }^{12}$ The shi emerged out of the conflicts of the Warring States, in which the autonomous city-states of the Western Zhou were gradually incorporated into larger states. Descendants of displaced and junior lineages took up service in the courts of more powerful states, offering specialist knowledge of texts and rituals. ${ }^{113}$ In early imperial China, the shi occupied a strategic position. The Han practice of government developed a strongly textual character, requiring a high level of literary competence on the part of the governing elite in practices such as record keeping, the writing of memorials, the transmission of orders and much else besides. ${ }^{114}$ This acquired an institutional basis with the creation of an imperial academy, where

\footnotetext{
${ }^{110}$ Wu 1989: 170-1; Barbieri-Low 2007: 163. ${ }^{111}$ Wu 1989: 170-86. ${ }^{112}$ Connery 1998.

113 Cheng 2001: 105-7; Barbieri-Low 2007: $37 . \quad{ }^{114}$ Connery 1998: 7-10; Cheng 2001: 105-6.
} 
candidates for government office were trained in mastery of canonical texts of the Confucian tradition, and in the commentaries which elucidated them and were a major category of shi textual production. Chinese 'literature' developed out of, and in relation to, the wide range of textual practices which the shi engaged in as part of their official duties. ${ }^{115}$

This textualisation of culture extended to visual art and informed the pictorialisation of history. Liu Xiang's Lienü Zhuan was translated into pictorial formats - screens and handscrolls - more or less contemporaneously with the production of the text, and under Liu Xiang's own direction. ${ }^{116}$ In the Eastern Han, the Emperor Ming instructed the historian Ban Gu (32-92) and Jia Kui (30-102), a well-known classical scholar, to make selections from classics and histories of stories which could be depicted by the painters of the Imperial Manufactory, in order to decorate the palace, probably as wall- or screen-paintings. Ban Gu and Jia Kui also provided the evaluative captions (zan) which anchored viewing of the images in the appropriate, textually prescribed, moral codes. ${ }^{117}$

We need not assume that the historical images we find in funerary contexts were based on models created at the imperial court - although in some cases ('Jing Ke', 'Two Peaches') the iconography is so consistent that a single prototype seems likely - or trace specific instances to specific texts, in order to see a parallel between the practices which informed the pictorialisation of history at the court and their counterparts in the funerary repertoire. The excerpting and juxtaposition of specific visual narratives parallel the textual practices of the shi less as historians than as compilers of 'treasuries of anecdotes' which could be drawn upon as rhetorical exempla ideally adjusted to a range of specific purposes. ${ }^{118}$ The contextually appropriate selection and application of anecdotes from such compilations were amongst the group-defining cultural practices of the shi. The historical narratives chosen for funerary contexts affirmed - alongside the innumerable pictures of the pupils of Confucius, and stories of filial piety - the commitment of the deceased to the core values which informed

115 Connery 1998: 141-6; Lewis 2007: 222-6.

116 Hanshu 30.1727; Wu 1989: 170-1; Barbieri-Low 2007: 163.

117 Zhang Yanyuan, Lidai Minghua Ji in Yu Anlan ed., Huashi Congshu 1963, juan 3: 56. BarbieriLow 2007: 196; Murray 2007: 33: the pictures may have been scrolls rather than screen- or wall-paintings. Possibly the paintings referred to by Zhang Yanyuan are versions on scrolls which may have served as models for palace decorations such as screens. Wu 1989: 193, parallel with Liu Xiang's selections of 'exemplary historical figures and events for the Shuo Yuan'.

118 Schaberg 2011: 389. Wu 1989: 173-9: Wu Liang's selection from Lienü Zhuan, focused on widows' preservation of chastity and responsibility towards the sons of their husbands, aimed at his widow. 
the imperial system of government and of which the shi were the social embodiment. ${ }^{119}$ Furthermore, they had a specifically political charge, whereby moral critique was clothed within manifest commitment to the ruling dynasty.

The later Eastern Han was an exceptionally problematic period for relations between the imperial court and the shi, who found themselves faced with conflicting pressures. Consort families were particularly powerful when the emperor was a minor, and they sought to arrogate the reins of government to themselves. Eunuchs, as personal servants in the inner court, were able to establish intimate relationships with the emperor and marginalise the shi officials of the outer court in the conduct of government, even placing their own favourites in posts. ${ }^{120}$ These abuses were the subject of protests and critical memorials by officials, but outspoken criticism of the court was sometimes met with reprisals, including dismissal and disqualification from office. ${ }^{121}$ Historical exempla informed the terms in which these political conflicts were fought out. Displaying the tribute that vice pays to virtue, the Empress Dowager Liang - having installed two child emperors in succession - announced her retirement from the role of regent with a quotation of the words attributed to the Duke of Zhou. In fact, control over the young Emperor Huan simply passed to the Dowager's brother, Liang Ji, until, some years later in $159 \mathrm{CE}$, Huan was able to assert his autonomy of Ji and his clan with the assistance of a eunuch coup. ${ }^{122}$

The use of historical images in tombs and especially funerary shrines (which could continue to be viewed even after the funeral and the closure of the tomb) should be seen against this background of political tensions and conflict. ${ }^{123}$ Funerals of scholars and officials were a major focus for the articulation of shi identity. Colleagues, friends and former fellow-students of the deceased travelled long distances to participate in memorial celebrations, and contributed to the erection of memorial tablets. ${ }^{124}$ More specifically, the la sacrifice - at which the deceased's ancestors were invoked and his own hun-soul was the recipient of offerings welcoming it to the shrine as its new abode ${ }^{125}$ - was specifically intended to 'rectify the relation between rulers and ministers', as well as establishing harmony in family relations and serving to 'adjust the relations between high and low'. ${ }^{126}$

\footnotetext{
119 Wu 1989: 180-5. ${ }^{120}$ Powers 1991: 207-8. ${ }^{121}$ Powers 1991: 261-3, 345-52.

122 Powers 1991: 209-10. ${ }^{123}$ Powers 1991; Thompson 1999; Lewis 2007: 200.

124 Powers 1984: 142-4; 1991: 97-103.

125 Hence the popularity of scenes of kitchens and feasting on shrines.

126 James 1996: 106-7, quoting Li Ji - Legge 1885: 27.369-72.
} 
The Duke of Zhou had long been seen as a model minister and official by the shi. On the death of King $\mathrm{Wu}$, the conqueror of the Shang and founder of the Zhou dynasty, the Duke of Zhou took on the role of regent for Wu's young son, King Cheng. An engraving from one of the Songshan shrines (Figure 8.13) depicts the scene with the child-king Cheng placed in the centre, standing on a podium, facing forward with a crown on his head. To either side he is flanked by officials, all leaning forward at their waists in a posture strongly coded as an expression of respect, holding their tablets of office. To the king's right, one official holds a protective parasol over his head, whilst, on his left, the Duke of Zhou kneels, with covered hands, to make report to the king concerning his conduct of official business, treating him with exactly the same ritual respect and propriety as would be appropriate to an adult emperor. ${ }^{127}$ Such images had an immediate relevance to the circumstances of the Eastern Han court, with a series of child emperors controlled by the consort family. Indeed, the use of the image of the Duke of Zhou for admonitory purpose already had excellent precedents. In his history of the Western Han, Ban Gu relates that the Emperor $\mathrm{Wu}$, nearing death, presented a painting of King Cheng and the Duke of Zhou to his minister Huo Guang (131-68 BCE), as an intimation that he was to act in a similar way on behalf of the emperor's eight-year-old son, Liu Fuling, whom he was designating as successor. ${ }^{128}$

'Two Peaches and Three Warriors' (Figure 8.11b) is an interestingly ambivalent story, and one of the most popular in Han tomb art. ${ }^{129}$ Set in the Spring and Autumn period, the story is one of the three brave warriors from the state of Qi. The diminutive prime minister Yanzi, whether personally slighted by the warriors or deeming their power a threat to himself or the state, persuaded the Duke of Qi to present the warriors with two peaches, to be distributed among them according to their merits. Two of the warriors boast of their prowess in warfare, and claim their peaches, the moment shown in the engraving; the third then trumps them with his account of a triumph over a monstrous river turtle. The first two return their peaches and, humiliated, commit suicide, as does the third, filled with remorse at being the unwitting cause of the death of his two friends. The

127 Powers 1984: 153: 'the Duke attempts to compress his physical bulk into a space commensurate with the inferior status he assumes ... Although the young king stands on a platform, in a space set apart by a parasol, and wears a three point crown, the highest point of his crown still falls short of the Duke's hat as he kneels before his lord.' Barbieri-Low 2007: 168: identification of the figure on the left holding the parasol as the Duke of Zhou in condensed versions of the scene.

128 Hanshu 68.2932; Barbieri-Low 2007: 167; James 1996: 95-6; Powers 1991: 209-10.

129 Eleven examples in Finsterbusch: Henan, Shandong, including Yinan and Wu family shrines. 
story could be interpreted in two ways, emphasising the loyalty of the minister to his lord, and his strategic intelligence, or the tragedy of the three warriors, undone by the low cunning of a devious courtier monopolising the ear of the ruler. The latter interpretation has obvious resonances with the fate of the danggu (黨錮), the shi critics of eunuch corruption at the court, who had been hounded out of office, harassed and persecuted even to the extreme of death by the eunuchs and their party. ${ }^{130}$ This is certainly the point of view of a Han poem on the subject, 'The Song of Mount Liangfu'. Departing from the capital of Qi, the poet stops and mourns at the warriors' three tombs: 'Their strength was such that they could move the Southern Mountain;/ Their wisdom exhausted the principles of the earth./But one morning they were slandered,/And two peaches killed the three heroes./Who could have made such a plot?/The Prime Minister Yanzi of Qi. ${ }^{\text {,131 }}$

Two stories from more recent history are particularly popular in the repertoire of Eastern Han funerary art, both concerning the First Emperor, Qin Shihuangdi: Jing Ke's attempted assassination of the King of Qin (Figure 8.12); and the First Emperor's failure to recover the Zhou Tripods (Figure 8.14). Fearful of Qin expansion, Prince Dan of Yan sought to attract resourceful advisers and retainers to his court, amongst them Jing Ke. Together they plotted an attempt to assassinate the King of Qin (later First Emperor). This involved Jing Ke winning the king's confidence by presenting him with the head of Fan Yuqi, a former Qin general now fugitive at the Yan court, and a map of some Yan territories as a token of submission. Inside the map-roll was concealed a dagger, which Jing $\mathrm{Ke}$ was to use to assassinate the king. The plot went awry. Jing Ke failed to take the king sufficiently by surprise, and, as Sima Qian tells the story, the two men end up pursuing each other around a column in the audience chamber, until the king is finally able to draw his sword. He wounds Jing $\mathrm{Ke}$, who is then subdued by the guards, not before a final desperate effort to kill the king, hurling the dagger which pierces the central column in the hall - the moment shown in the picture. ${ }^{132}$ This scene is one of the most frequently recurring in Han funerary art, and found in many different regions in China. ${ }^{133}$ Pictures of the story of the First Emperor's loss of the Zhou Tripods are similarly popular and widespread in their

\footnotetext{
130 Thompson 1999: 13.

131 Chaves 1968: 10 (trans.); Thompson 1999: 16-17 Yinan; Ruitenbeek 2002: 41-2 Songshan.

132 Shiji 86.

133 Finsterbusch I.71, 85, 324, 463; III.A84, A252, E400, I17, O22, IV.B122; not including the three examples on the $\mathrm{Wu}$ family shrines, a second example from the Mahao tombs in Sichuan (Rudolph and Yu 1951: 19; Tang 1997), or the scene on the Gao Yi Que in Sichuan (Paludan 1991: 36).
} 
distribution. ${ }^{134}$ According to legend, the Nine Tripods had originally been cast by the Xia, the founding dynasty of China, out of bronze submitted by the nine regions as tribute. ${ }^{135}$ Amongst other miraculous powers, these precious treasures embodied imperial legitimacy. Shining brightly or fading as the mandate of a dynasty waxed and waned, they had in turn been transmitted from the Xia to the Shang and the Shang to the Zhou, only to be lost in the River Si with the final collapse of the Zhou in 327 BCE. After reunifying China, the First Emperor sent an expedition to the River Si, to recover the tripods which had reportedly surfaced. The pictures show imperial officials assembled around some kind of gantry, equipped with pulleys and ropes, whereby they seek to raise one of the tripods. They are thwarted by a dragon, which bites through the rope, leaving the officials to fall over on each other, as the tension in the rope disappears. ${ }^{136}$

Both of these pictures could be seen as manifestations of loyalty to the Han, whose legitimacy partly rested on the claim that the First Emperor was a tyrant who had lost - if he ever held - the mandate to rule. But they also had a critical edge. Part of their appeal - to a shi audience - seems to have been the way in which they bring the emperor down to the same level as the $s h i$, "who considered themselves "teachers and friends" of the rulers, rather than mere subjects'. ${ }^{137}$ In both cases the scene is given a distinctly comic treatment, hardly conformable with imperial dignity. It is a rather galumphing emperor who rushes around the column, in flight from Jing Ke; and the officials, falling back on their bottoms as the rope snaps, bitten through by the dragon, stand in striking contrast to their more conventional representation as embodiments of corporeal propriety, respectfully bowing to their superiors, as in the scenes of the Duke of Zhou and King Cheng. It was a topos of Han historical thought that the 'Yin [Shang] could have used the Xia as a mirror, and the Zhou could have used the Yin as a mirror.' ${ }^{138}$ So too, the unworthiness of the autocratic First Emperor, manifested by his harsh treatment of scholars, might be a mirror for the emperors of the late Han. More significantly, the scene of the loss of the tripods signalled not only that the mandate of Heaven was changeable, but even that 'the age of ritual art' had ended, ${ }^{139}$

\footnotetext{
134 Finsterbusch I.169, 193, 261k, 368; III.A134, E871, E872, O44, O50c, O148, O155, O158, O187, O191, O287, O357; IV.A358.

135 Wu 1989: 92-6; Marsili 2005.

136 James 1985: 287-9; Wu 1989: 92-6; James 1996: 54-5, 120-3 disregarding the story of the dragon biting through the rope as specifically associated with Qin Shihuangdi in later texts Wu 1989: 96.

137 Pines 2008: 24. ${ }^{138}$ Han shi wai zhuan 19, trans. Hightower 1952: 178-9.

139 Wu 1996: 11.
} 
and that forms of legitimacy dependent on a purely ritual aura, transmitted within the ancestral line and the ancestral temples of the ruling family, were increasingly displaced by a more publicly accountable moral authority, which the shi were the best placed to judge, and which pictorial histories explored.

All these images offer material for political reflection, corresponding to the admonitory role attributed by Wang Wenkao to the paintings of the Numinous Hall. This understanding of the role of pictures of historical events was part of the broader concept of history as 'mirror'. This topos of shi thought was already an old one by the Han: the text from Master Han's 'Outer Commentary to the Book of Poetry' quoted above was commenting two lines of a poem in the Classic of Poetry and spelling out their implications. The topos obviously informed the beginnings of what we tend to classify as history writing proper in the Shiji of Sima Qian. But it is clear that the concept was also extended to pictures of history in the Han. A passage in the Kongzi Jiayu, a late Han compilation of stories about the life of Confucius, describes Confucius visiting the Ming-Tang (Bright Hall):

He saw on the four gates and walls the countenances of Yao and Shun, and images of Jie and Zhou, showing the good and bad characters of each and giving warning by their success or failure. There was also [a picture of] the Duke of Zhou acting as minister to King Cheng, holding him in his arms with his back to the hatchetscreen, and with his face towards the south to receive in audience the feudal lords. Confucius walked to and fro looking at them, and said to his followers: 'This is why the House of Zhou has prospered. A bright mirror is the means by which one examines the face's form, the past is the means by which one knows the present. ${ }^{140}$

A comment attributed to Cao Zhi (192-232 CE) praises the moral efficacy of visual depictions of history: 'There is none who seeing a picture of usurping ministers stealing a throne would not grind his teeth ... Who at the sight of loyal vassals dying for their principles would not harden his own resolve; and who would not sigh at beholding banished ministers and persecuted sons ... From this we may know that paintings are the means by which mirrors and admonitions are preserved. ${ }^{, 14}$ The character translated 'mirror' in both the Han shi wai zhuan passage and the comment attributed to Cao Zhi requires discussion. Jian 鑒 as a noun means 'mirror', as a verb 'to scrutinise'. The base of 鑒 is the metal radical; on top of it is the homophone 監, indicating a man lying down and looking into a sacrificial vessel, probably filled with water, and entailing self-scrutiny of a divinatory

140 Kongzi jiayu, pt 3, page 2; Drake 1943: 287.

141 Acker I.74-5; translation modified, cf. Wang 1994: 517. 
character - as it appears in the Shang oracle bones. ${ }^{142}$ Consequently, the concept of the painting as 'mirror' in this cultural context has none of the disparaging connotations that the comparison of painting with a mirror has in some strands of Greek thought, notably that of Plato. ${ }^{143}$ On the contrary, the vocabulary implies a close and critical scrutiny, a deep divinatory viewing of the patterns of the past in order to construe the events of the future, ideally anticipating and averting disaster by applying the lessons of the past in the present, specifically through moral rectification of oneself and moral admonition of one's colleagues and superiors. ${ }^{144}$

This implies a very different kind of spectatorship than the affirmative 'theoric' viewing afforded by classical Greek history paintings. Greek historical pictures operated above all through beautiful surfaces, iconographic parallels like the Tyrannicide imagery in the Marathon frieze, which created superficial, highly ideological parallels between myth, history and present action. ${ }^{145}$ Congruent with the divinatory, critical, style of viewing, the monumentality of Chinese pictorialisation of history is a rather intimate monumentality, by comparison with the imposing stoas and temples which were the architectural support for historical pictures in classical Athens. Even in the case of the largest surviving Han funerary shrine, the Xiaotangshan, the viewer needs to kneel to view the pictures. It is hard to imagine more than one viewer at a time looking at smaller shrines, like those from Songshan. The viewer, kneeling in front of the shrine, making offerings to the deceased (and thus echoing the homage scene which commonly decorated the back wall of shrines), would read the imagery, simply by turning his head from right to left, or vice versa, and up and down, like studying a written text, as Wu Hung has suggested. This is radically different from the very public and collective viewing context for the Marathon painting in the Stoa Poikile, and even more so for the battle friezes on the temple of Athena Nike, looked up to from a distance by the

142 Huang 1995: 76. The links between mirroring, history and divinatory prognostication are also apparent in a saying of Mozi, quoted in the Shiji 79/47: 'I have said that he who looks into water will see the form of his face, but he who looks at men will know fortune ( $j i$ 吉) and misfortune (xiong 凶)', invoking the terminology of divination (Watson 1958: 136): the character for 'fortune' shows words from the mouth of a shi/scholar.

143 Republic 596de.

144 The divinatory affordances of mirrors, and their moral potential as media of self-scrutiny, are similarly developed in Greco-Roman culture, along with plays on the notion of painting as a moralising mirror, particularly in Roman art (Taylor 2008); in classical Athens, however, they do not seem to have been linked to history painting in the way they were in China.

145 Which led to disaster, as Thucydides (6.53-9) seeks to show in his deconstruction of the Tyrannicide myth against the background of the Athenian expedition to Sicily, which ultimately lost Athens the Peloponnesian War. 
viewer, as he approaches the entrance to the Akropolis, processing up the sacred way, the route for the Panathenaic procession. Of course, there is a danger of being misled by the character of the very partial surviving material evidence, the funerary shrines of the shi. The depictions of history as wall-paintings in palaces may have had a more monumental character. But it is worth bearing in mind that the texts discussing the production and viewing of such paintings within the context of the palace more often refer to more personal objects, screens and even handscrolls, than wallpaintings, and even if some of those paintings were more monumental, it should not distract us from identifying the specific character of the elaboration of the practice of picturing history in late Han China, evidenced by funerary art. As in late fifth-century Athens, so also in second-century CE China, and in particular in the Shandong region, we encounter an intensified interest in the pictorialisation of history, but informed by rather different interests on the part of its primary sponsors, the shi, and correspondingly having rather different purposes: namely formulating and encouraging a broadly critical orientation towards the state and state power - or at least its abuse - in contrast to the ideological idealisation of imperialism in the art of the Athenian state.

\section{Conclusion}

Long-term comparative social history of art as an institution avoids either essentialising contrasts between the two traditions or a reductive assimilation of them in terms of a handful of minimal common denominators. Focusing on strategies for 'staging' history, and the agents who manage such stagings, demonstrates how the broadly comparable strategies of historical representation in early Greece and China are given a specific shape by the distinctive character of their respective sponsoring elites, as actors in the complex configurations which constituted the states in each case. The 'memory objects' of Zhou China and archaic Greece have little that is formal in common, but they both operate in the context of ancestralising strategies which bear at least a family resemblance to each other. To be sure, those ancestralising strategies are significantly different, but we can explain those differences in terms of differences in political and social structure: aristocratic lineages securely established as the rulers of autonomous city-states and competing for office and status within the broader field of the loosely integrated Zhou kingdom in Bronze Age China, as opposed to aristocratic lineages struggling for dominance primarily within 
the emergent poleis of archaic Greece, against the background of panHellenic relations of guest-friendship and of competition, in festival and games, within a loose civilisational framework that lacked the higher-level political organisation characteristic of the Zhou kingdom.

Traditions of picturing history in classical Greece and early imperial China developed out of this broadly comparable background. This took place in a comparable political context, namely the emergence of more differentiated state structures, entailing new forms of specifically political solidarity transcending kinship, and also a much extended dependence for state administration on elites with a high level of textual competence, the shi of China and the rhètores and stratēgoi of classical Athens. The role and significance of the pictorialisation of history were refracted through the different structures of the two states, and the positions of the cultural elites within them. Depictions of military victory, celebrating the state through the Athenian people, were the focus of Athenian picturing of history, shaped by the interests of the demos, who were the primary patrons of state art, and their rather direct control, through the institutions of the democratic assembly, over the political and cultural elites who were responsible for realising projects like the paintings of the Stoa Poikile or the sculptures of the Temple of Athena Nike. In China, by contrast, the state apparatus was much more complex, and power balanced uneasily between the shi and the bureaucracy of the outer court, and the eunuchs and the consort families of the inner court, all competing for the ear of the emperor. Athenian historical representation was directed primarily towards relations outside the state, with the Persians and with other Greeks. Chinese picturing of history was directed towards the inner workings of the state, in particular to exploring and regulating the relationship between the shi and other holders of state power, including the emperor. It defined that relationship in ways which questioned uses of state power which might seem arbitrary from a shi point of view, and supported the moral authority of the shi as the paramount cultural elite.

\section{References}

Acker, W. R. B. (1954-74) Some T'ang and Pre-T'ang Texts on Chinese Painting, 3 vols. Leiden.

Akiro, K. (2010) 'Are the Wu Liang Shrine pictorial stones forgeries? Examining the Han era evidence', Asia Major 23.2: 129-51.

Alonso, A. M. (1988) 'The effects of truth: representations of the past and the imagining of community', Journal of Historical Sociology 1.1: 33-57. 
Antonaccio, C. (1994) 'Contesting the past: hero cult, tomb cult and epic in early Greece', American Journal of Archaeology 98.3: 389-410.

Assmann, J. (2011) Cultural Memory and Early Civilization: Writing, Remembrance and Political Imagination. Cambridge.

Bagley, R. W. (1980a) 'The rise of the Western Zhou dynasty', in The Great Bronze Age of China, ed. W. Fong. New York: 193-213.

(1980b) 'Transformation of the bronze art in later Western Zhou', in The Great Bronze Age of China, ed. W. Fong. New York: 241-8.

Bai Qianshen (2008) 'The intellectual legacy of Huang Yi and his friends: reflections on some issues raised by Recarving China's Past', in Rethinking Recarving: Ideals, Practices and Problems of the 'Wu Family Shrines' and Han China, ed. C. Liu. New Haven: 286-337.

Barbieri-Low, A. J. (2007) Artisans in Early Imperial China. Seattle and London.

Boedeker, D. (1998) 'Presenting the past in fifth century Athens', in Democracy, Empire and the Arts in Fifth Century Athens, eds. D. Boedeker and K. Raaflaub. Cambridge, MA: 185-202.

Castriota, D. (1992) Myth, Ethos and Actuality: Official Art in Fifth Century BC Athens. Madison.

Chaves, J. (1968) 'A Han painted tomb at Loyang', Artibus Asiae 30: 5-27.

Cheng, A. (2001) 'What did it mean to be a Ru in Han times?', Asia Major 14.2: 101-18.

Connery, C. L. (1998) The Empire of the Text: Writing and Authority in Early Imperial China. Oxford.

Connor, W. R. (1970) 'Theseus in Classical Athens', in The Quest for Theseus, ed. A. Ward. New York: 143-74.

Cook, C. (2005) 'Moonshine and millet: feasting and purification rituals in ancient China', in Of Tripod and Palate: Food, Politics and Religion in Traditional China, ed. R. Sterckx. London: 9-33.

Croissant, D. (1964) 'Funktion und Wanddekor der Opferschreine von Wu Liang Tz'u: typologische und ikonographische Untersuchungen', Monumenta Serica 23: 88-162.

Csapo, E. and Miller, M. (1998) 'Democracy, empire and art: towards a politics of time and narrative', in Democracy, Empire and the Arts in Fifth Century Athens, eds. D. Boedeker and K. Raaflaub. Cambridge, MA: 87-125.

Day, J. W. (1989) 'Rituals in stone: early Greek grave epigrams and monuments', Journal of Hellenic Studies 109: 16-28.

Detienne, M. (2007) The Greeks and Us: A Comparative Anthropology of Ancient Greece. Cambridge.

Drake, F. S. (1943) 'Sculptured stones of the Han dynasty', Monumenta Serica 8: 280-318.

Duyvandak, J. J. L. (1939-40) 'An illustrated battle account of the Former Han Dynasty', T'oung Pao 34: 249-64; 35: 211-15.

Falkenhausen, L. von. (2005) 'The inscribed bronzes from Yangjiacun: new evidence on social structure and historical consciousness in Late Western Zhou China (ca. 800 BC)', Proceedings of the British Academy 139: 239-95. 
Fearn, D. (2010) 'Aeginetan epinician culture: naming, ritual and politics', in Aegina: Contexts for Lyric Poetry: Myth, History and Identity in the Fifth Century BC, ed. David Fearn. Oxford: 175-226.

Finsterbusch, K. (1966-2004) Verzeichnis und Motivindex der HanDarstellungen, 4 vols. Wiesbaden.

Forke, A. (1907) Lun-Heng: Philosophical Essays of Wang Ch'ung, 2 vols. London.

Frisby, D. (1992) The Alienated Mind: The Sociology of Knowledge in Germany, 1918-1933. London.

Gernet, L. (1981) 'The mythical idea of value in Greece', in The Anthropology of Ancient Greece. London: 73-111.

Goldstein, C. (1996) Teaching Art: Academies and Schools from Vasari to Albers. Cambridge.

Grethlein, J. (2008) 'Memory and material objects in the Iliad and the Odyssey', Journal of Hellenic Studies 128: 27-51.

Hansen, P. A. (1983) Carmina epigraphica graeca saeculorum VII-V a. Chr. n., Texte und Kommentare XII. Berlin and New York.

Harrison, E. (1972) 'The south frieze of the Nike Temple and the Marathon Painting in the Painted Stoa', American Journal of Archaeology 76: 353-78. (1996) 'Pheidias', in Personal Styles in Greek Sculpture, eds. O. Palagia and J. J. Pollitt. Cambridge: 16-65.

Hartog, F. (2000) 'The invention of history: the prehistory of a concept from Homer to Herodotus', History and Theory 39.3: 384-95.

(2003) 'Ordres du temps et régimes de historicité', Divinatio 17: 71-90.

Henle, J. (1973) Greek Myths: A Vase-Painter's Notebook. London.

Hightower, J. R. (1952) Han shi wai zhuan: Han Ying's Illustrations of the Didactic Application of the Classic of Songs. Cambridge, MA.

Hirsch, E. and Stewart, C. (2005) 'Introduction: ethnographies of historicity', History and Anthropology 16.3: 261-74.

Hölscher, T. (1973) Griechische Historienbilder des 5. und 4. Jahrhunderts v. Chr. Würzburg.

(1988) 'Tradition und Geschichte: Zwei Typen der Vergangenheit am Beispiel der griechischen Kunst', in Das kulturelle Gedächtnis: Schrift, Erinnerung und politische Identität in frühen Hochkulturen, eds. J. Assmann and T. Hölscher. Munich: 115-49.

Huang Chun-chieh (1995) 'Historical thinking in classical Confucianism: historical argumentation from the Three Dynasties', in Time and Space in Chinese Culture, eds. C. Huang and E. Zürcher. Leiden: 72-85.

James, J. M. (1985) 'Interpreting Han funerary art: the importance of context', Oriental Art 31.3: 283-92.

(1988/9) 'The iconographic programme of the Wu family offering shrines', Artibus Asiae 49.1/2: 39-72.

(1996) A Guide to the Tomb and Shrine Art of the Han Dynasty 206 BC - AD 220. Lampeter.

Karusos, C. (1961) Aristodikos: zur Geschichte der spätarchaisch-attischen Plastik und der Grabstatue. Stuttgart. 


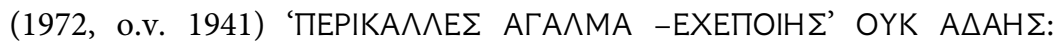
Empfindungen und Gedanken der archaischen Griechen um die Kunst', in Inschriften der Griechen, ed. G. Pfohl. Darmstadt: 85-152.

Keightley, D. N. (1990) 'Early civilization in China: reflections on how it became Chinese', in Heritage of China: Contemporary Perspectives on Chinese Civilization, ed. P. Ropp. Berkeley: 15-54.

Kern, M. (2009) 'Bronze inscriptions, the Shijing and the Shangshu: the evolution of the ancestral sacrifice during the Western Zhou', in Early Chinese Religion, Part One: Shang through Han (1250 BC - 220 AD), eds. J. Lagerwey and M. Kalinowski. Leiden: 143-200.

Knechtges, D. R. (trans.) (1987) Xiao Tong: Wen Xuan or Selections of Refined Literature, vol. II: Rhapsodies on Sacrificing, Hunting, Travel, Sightseeing, Palaces and Halls, Rivers and Seas. Princeton.

Langdon, S. (1987) 'Gift exchange in the Geometric sanctuaries', in Gifts to the Gods, eds. T. Linders and G. Nordquist. Uppsala: 107-13.

Legge, J. (trans.) (1885) Li Ki, in Sacred Books of the East, ed. F. M. Muller, vols. XXVII-XXVIII. Oxford.

Lewis, M. E. (2006) The Construction of Space in Early China. New York.

(2007) The Early Chinese Empires: Qin and Han. Cambridge, MA.

Li Feng (2008) Bureacracy and the State in Early China. Cambridge.

Lippmann, M., Scahill, D. and Schultz, P. (2006) 'Knights 843-59, the Nike Temple Bastion, and Cleon's shields from Pylos', American Journal of Archaeology 110.4: 551-63.

Liu, C., Nylan, M. and Barbieri-Low, A. (2005) Recarving China's Past: Art, Archaeology and Architecture of the 'Wu Family Shrines'. New Haven.

Lloyd, G. E. R. (2002) The Ambitions of Curiosity: Understanding the World in Ancient Greece and China. Cambridge.

(2011) 'Epilogue', in The Oxford History of Historical Writing, vol. I: Beginnings to $A D$ 600, eds. A. Feldherr and G. Hardy. Oxford: 601-19.

Loewe, M. (ed.) (1993) Early Chinese Texts: A Bibliographic Guide. Berkeley.

Loraux, N. (1986) The Invention of Athens: The Funerary Oration in the Classical City. Cambridge, MA.

Marsili, F. (2005) 'Tripod vessel (ding)', in Recarving China's Past: Art, Archaeology and Architecure of the 'Wu Family Shrines', eds. C. Liu, M. Nylan and A. Barbieri-Low. Princeton: 315-21.

Morris, I. (2000) Archaeology as Cultural History: Words and Things in Iron Age Greece. Cambridge.

Mullen, W. (1982) Choreia: Pindar and Dance. Princeton.

Murray, J. K. (2007) Mirror of Morality: Chinese Narrative Illustration and Confucian Ideology. Honolulu.

Mutschler, F.-H. (1997) 'Vergleichende Beobachtungen zur griechischroemischen und altchinesischen Geschichtsschreibung', Saeculum 48: 213-53.

Neer, R. (2011) The Emergence of the Classical Style in Greek Sculpture. Chicago. 
Nightingale, A. (2001) 'On wandering and wondering: theoria in Greek philosophy and culture', Arion 9.2: 23-58.

(2004) Spectacles of Truth in Classical Greek Philosophy: Theoria in its Cultural Context. Cambridge.

Osborne, R. (1996) Greece in the Making, 1200-479 BC. London.

Paludan, A. (1991) The Chinese Spirit Road: The Classical Tradition of Stone Tomb Statuary. New Haven.

Parker, R. (1996) Athenian Religion: A History. Oxford.

Pines, Y. (2008) 'A hero terrorist: adoration of Jing Ke revisited', Asia Major 21.1: $1-34$.

Porter, J. I. (2011) The Origins of Aesthetic Thought in Ancient Greece: Matter, Sensation and Experience. Cambridge.

Powers, M. (1984) 'Pictorial art and its public in early imperial China', Art History 7.2: 135-63.

(1991) Art and Political Expression in Early China. New Haven.

Prusek, J. (1970) 'History and epics in China and in the West: a study of differences in conception of the human story', in Chinese History and Literature: Collection of Studies. Dordrecht: 17-34.

Raaflaub, K. (1997) 'Homeric society', in A New Companion to Homer, eds. I. Morris and B. Powell. Leiden: 624-58.

Rawson, J. (1999) 'Chinese burial patterns: sources of information on thought and belief, in Cognition and Material Culture: The Archaeology of Symbolic Storage, eds. C. Renfrew and C. Scarre. Cambridge: 107-33.

Reinach, A. (1921) Textes grecs et latins relatifs à l'histoire de la peinture ancienne. Paris.

Rouveret, A. (1987/9) 'Les lieux de la mémoire publique: quelques remarques sur la fonction des tableaux dans la cité', Opus 6/7: 101-24.

Rudolph, R. C. and Wen Yu (1951) Han Tomb Art of West China: A Collection of First- and Second-Century Reliefs. Berkeley.

Ruitenbeek, K. (2002) Chinese Shadows: Stone Reliefs, Rubbings and Related Works of Art from the Han Dynasty (206 BC-AD 220) in the Royal Ontario Museum. Ontario.

Rusen, J. (1996) 'Some theoretical approaches to intercultural comparative historiography', History and Theory 35.4: 5-22.

Schaberg, D. (2011) 'Chinese history and philosophy', in The Oxford History of Historical Writing, vol. I: Beginnings to $A D$ 600, eds. A. Feldherr and G. Hardy. Oxford: 394-414.

Shankman, S. and Durrant, S. (2000) The Siren and the Sage: Knowledge and Wisdom in Ancient Greece and China. London.

Shaughnessy, E. L. (1991) Sources of Western Zhou History: Inscribed Bronze Vessels. Berkeley.

(1999) 'Bronzes from Hoard 1, at Zhuangbai, Fufeng, Shaanxi Province', in The Golden Age of Chinese Archaeology, ed. Yang Xiaoneng. New Haven: 236-47.

Schultz, P. (2009) 'The north frieze of the temple of Athena Nike', in Art in Athens during the Peloponnesian War, ed. O. Palagia. Cambridge: 128-67. 
So, J. (1980a) 'New departures in Eastern Zhou bronze designs: the Spring and Autumn period', in The Great Bronze Age of China, ed. W. Fong. New York: 250-69.

(1980b) 'The inlaid bronzes of the Warring States period', in The Great Bronze Age of China, ed. W. Fong. New York: 304-20.

Soper, A. C. (1974) 'The purpose and date of the Hsiao-tang Shan offering shrine: a modest proposal', Artibus Asiae 36: 249-65.

Stansbury-O'Donnell, M. D. (2005) 'The painting programme in the Stoa Poikile', in Periklean Athens and its Legacy, eds. J. Barringer and J. Hurwit. New Haven: 73-87.

Steiner, D. T. (2001) Images in Mind: Statues in Archaic and Classical Greek Literature. Princeton.

Stewart, A. (1985) 'History, myth and allegory in the program of the temple of Athena Nike, Athens', in Pictorial Narrative in Antiquity and the Middle Ages, eds. H. L. Kessler and M. S. Simpson. Washington, DC: 53-73.

(1986) 'When is a kouros not an Apollo? The Tenea "Apollo" revisited', in Corinthiaca: Studies in Honour of Darrell A. Amyx, ed. M. del Chiaro. Columbia, MO: 54-70.

(1997) Art, Desire and the Body in Ancient Greece. Cambridge.

Tang Changshou (1997) 'Shiziwan Cliff Tomb, no. 1', Orientations 28.8: 72-7. Tanner, J. (2006) The Invention of Art History in Ancient Greece: Religion, Society and Artistic Rationalisation. Cambridge.

Taylor, J. G. (1998) 'Oinoe and the Painted Stoa: ancient and modern misunderstandings', American Journal of Philology 119.2: 223-43.

Taylor, R. (2008) The Moral Mirror of Roman Art. Cambridge.

Thompson, L. (1998) 'The Yi'nan Tomb: narrative and ritual in pictorial art of the Eastern Han (25-220 CE)', PhD dissertation, New York University.

(1999) 'Confucian paragon or popular deity? Legendary heroes in a late Eastern Han tomb', Asia Major 12.2: 1-38.

Wang, E. (1994) 'Mirror, death and rhetoric: reading later Han Chinese bronze artefacts', Art Bulletin 84.3: 511-34.

Watson, B. (1958) Ssu-ma Ch'ien: Grand Historian of China. New York.

Whitley, J. (1994) 'The monuments that stood before Marathon: tomb cult and hero cult in archaic Attica', American Journal of Archaeology 98.2: 213-30.

(2001) The Archaeology of Greece. Cambridge.

Wu Hung (1989) The Wu Liang Shrine: The Ideology of Early Chinese Pictorial Art. Stanford.

(1996) Monumentality in Early Chinese Art and Architecture. Stanford.

Yang Xiaoneng (ed.) (1999) The Golden Age of Chinese Archaeology. New Haven.

Zhou Yiqun (2010) Festivals, Feasts and Gender Relations in Ancient China and Greece. Cambridge. 